\title{
On biospeleothems from a Venezuelan tepui cave: U-Th dating, growth rates, and morphology
}

\author{
Joyce Lundberg ${ }^{1 *}$, Charles Brewer-Carias ${ }^{2}$, and Donald A. McFarlane ${ }^{3}$ \\ ${ }^{1}$ Department of Geography and Environmental Studies, Carleton University, Ottawa, Ontario, K1S 5B6, Canada \\ ${ }^{2}$ Sociedad Venezolana de Ciencias Naturales, Caracas, Venezuela \\ ${ }^{3}$ W.M. Keck Science Center, The Claremont Colleges, 925 North Mills Avenue, Claremont, CA 91711, USA
}

\begin{abstract}
Seven silica biospeleothems from Cueva Charles Brewer, Chimantá Plateau, Venezuela have been successfully $U$-Th dated despite very low $U$ and high detrital Th concentrations. Growth rates are low, between $\sim 100$ to $\sim 800 \mu \mathrm{m} / \mathrm{ka}$, and are greater closer to water level. Dates in unaltered material are in good stratigraphic order, but secondary silicification may compromise the U-Th system, yielding unreliable sequences of ages. Detritally-enriched layers correlate with global climate cycles of the Late Quaternary, in particular the cooler, drier phases of MIS $5 \mathrm{~d}, 5 \mathrm{a}$, and 4 . SEM studies indicate that the peloidal material is made up of silica nano-particles assembled to form hollow tubules $\sim 1 \mu \mathrm{m}$ in diameter. Secondary silicification inside and outside the tubules fills most of the pores. Barite crystals are deposited close to the silicified core material. Chemical analyses suggest that the white peloidal material is deposited by stream-generated foam, while the silicified material and dark core material are closer to rock composition.
\end{abstract}

Keywords: $\quad$ silica speleothem, biospeleothem, sandstone, cave, U-Th, SEM, tepui

Received 3 June 2018; Revised 27 September 2018; Accepted 28 September 2018

Citation: Lundberg J., Brewer-Carías C. and McFarlane D.A., 2018. On biospeleothems from a Venezuelan tepui cave: U-Th dating, growth rates, and morphology. International Journal of Speleology, 47 (3), 361-378. Tampa, FL (USA) ISSN 0392-6672

https://doi.org/10.5038/1827-806X.47.3.2212

\section{INTRODUCTION}

The tepuis of Venezuela are home to an extraordinary suite of caves developed in PreCambrian arenites, and, like many of the other caves, Cueva Charles Brewer (Chimantá Plateau, Churí tepui, 05²14'51.63"N, $06^{\circ} 01^{\prime} 36.68^{\prime \prime}$, 2100 masl, Fig. 1) hosts many silica speleothems, several types of which have been shown to be biologically mediated. In overt recognition that biological activity is the prime agent governing their deposition, they have been dubbed "biospeleothems" (Brewer-Carías, 2005; Chacón et al., 2006; Aubrecht et al., 2008, 2012). In 2010 we reported the first attempt to U-Th date one of these (Lundberg et al., 2010), the results encouraging us to engage in further dating efforts. A relatively less successful dating effort (Sauro et al., 2013) was attributed to the altered and eroded nature of the samples. Here we report on the next phase of this research, where seven samples of biospeleothem from Cueva Charles Brewer (CBC) have been successfully dated, and studied under scanning electron microscope.

\section{Background to the region}

The background geology, speleogenesis, and environments of the region have been well treated elsewhere and are not repeated here. The geology of the region is briefly summarized in Lundberg et al. (2010) and Aubrecht et al. (2012). More complete accounts can be found in Briceño et al. (1990), Briceño \& Schubert (1990), Gibbs \& Barron (1993), Mecchia \& Piccini (1999), Doerr (1999), Santos et al. (2003), Piccini \& Mecchia (2009), and Aubrecht et al. (2011). The caves, their speleothems, and most of the known research at the time are summarized at length in Aubrecht et al. (2012). Further readings can be found in Piccini (1995), Piccini \& Mecchia (2009), and Sauro (2014). Climate, ecosystems and Pleistocene changes are described in Schubert \& Fritz (1985), Curtis et al. (1999), Pennington et al. (2000), Van der Hammen \& Hooghiemstra (2000), Rull (2004), Rull (2005), Nogué et al. (2009), Rull et al. (2010), and Zinck \& Huber (2011 and references therein).

\section{The speleothems}

Aubrecht et al. (2012) present a very detailed survey of speleothems from several caves of the Venezuelan tepuis. Most of the speleothems are siliceous; some are formed by inorganic precipitation (such as precipitation from ceiling drips to form silica stalactites, or from flowing water to form silica flowstone, or by deposition from aerosols onto cobwebs), but the majority show 


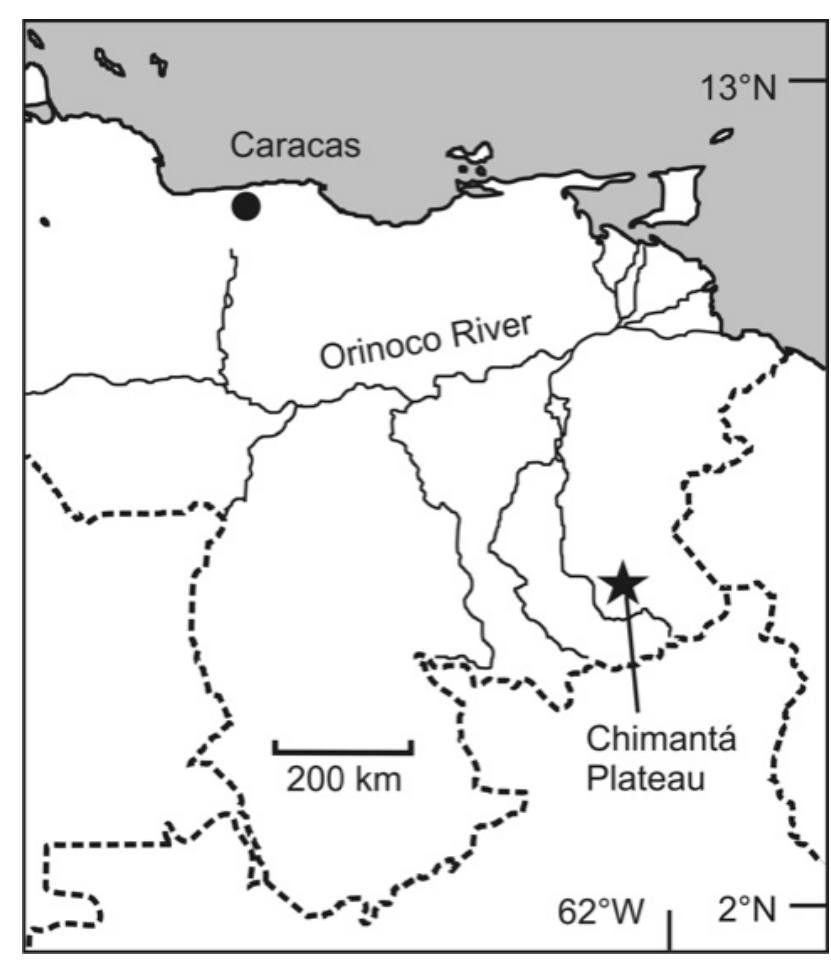

Fig. 1. Location of Cueva Charles Brewer, Chimantá Plateau, south-eastern Venezuela.

evidence of microbial mediation (Carreño \& Urbani, 2004; Aubrecht et al., 2008, 2012). Biospeleothems generally accrete in a stromatolitic manner and Aubrecht et al. (2012) consider them to be true stromatolites. Most have extraordinary shapes by comparison with speleothems from limestone caves. They come in several forms, the distinctions between forms not always clear-cut. Aubrecht et al. (2012) suggest three main categories: 1) "black corals" - a very good name to describe these multi-branched forms that look similar to evaporitic popcorn, but are very dark in colour; 2) "dolls" (or "muñecos") a vaguely columnar form that usually has a white base and a narrower, dark-brown tip (unfortunately, Aubrecht et al. describe them as "mushroom-shaped" - an adjective that immediately becomes confusing with the next category); and 3) "champignons" - ballshaped white speleothems.

In this present study, we focus only on the biologically mediated speleothems - the "biospeleothems", and on those with the simplest shapes, most likely to show a clear pattern of growth. Although the external forms may vary, Aubrecht et al. (2012) observe that most of the depositional material in the biospeleothems can be grouped into two categories: 1) dense, columnar stromatolitic material, of clear or brown opal; and 2) porous, laminated peloidal microbialite material. We examined both materials, but focussed our dating efforts on the peloidal material.

\section{METHODS}

Samples were sectioned with a thin lapidary saw. Due to the delicate nature, these materials cannot be polished (as is common to clarify the internal structures of calcite speleothems). The peloidal material can relatively easily be drilled out or even scraped out with the fine scalpel. Because the dense opaline material is so very hard, it is considerably more difficult to drill, requiring a very good quality thin diamond disc to avoid contaminating the sampled powder with metal dust from a drill bit. U-Th dating was done at Carleton University, Ottawa, Canada, using thermal ionization mass spectrometry (TIMS), following the methods outlined in Lundberg et al. (2010). At almost every step, processing of these silica speleothems was considerably more problematic than for calcite speleothems. Because the speleothems grew so slowly, samples had to be drilled in narrow bands along growth lines, but growth lines are hard to see in this very white material. The dissolution step requires the added precautions of using HF acid. During the mass spectrometry stage, the extremely low uranium contents of most samples severely limited the precision attainable from counting statistics, while at the same time, the very low U/Th ratio and relatively high detrital thorium content limited the efficiency of thorium ionization. Ages were calculated using standard decay equations (e.g., Ivanovich et al., 1992) and activity ratios calculated using half-lives from Cheng et al. (2013). Ages were adjusted for detrital contamination using the standard crustal silicate activity ratio ${ }^{230} \mathrm{Th} /{ }^{232} \mathrm{Th}$ of $0.83 \pm 0.42$ (e.g., following Cruz et al., 2005).

Scanning electron microscopy (SEM) and energy dispersive X-ray spectroscopy (EDS) were done at the Nano-imaging Facility of Carleton University, Ottawa, Canada. Chemical analyses were done commercially by Activation Labs, Ancaster, Ontario, Canada. As an easy way of testing the extent of secondary silicification, hardness was tested using a hardness pick set from MineraLab LLC, Arizona.

Statistical processing was done using the free software package PAST (Hammer et al., 2001). X-ray imaging of the small samples was done on a Siemens Dentotime machine in Westboro Family Dentistry, Ottawa.

\section{RESULTS}

\section{The samples and the dating results}

Seven samples were taken, six of them of the champignon type (TH, AMP, SH, ICB, FA, ON), and one of the doll type (FR). Appendix 1 presents the isotopic measurements and the ages. The ages are given first as the original calculated age and the 2 sigma absolute errors, and then as the age adjusted for detrital thorium content. In the text below, ages are quoted as calculated ages with adjusted ages in parentheses: e.g., "45 $\pm 2(35 \pm 4) \mathrm{ka}$ " indicates a calculated age of $45 \mathrm{ka}$ but adjusted for detrital content to $35 \mathrm{ka}$.

All the champignon-type samples were collected from the same area, from the thinly-bedded geological unit (one of the units rich in biospeleothems) which we call "The Mushroom Farm", above a bedrock shelf about $8 \mathrm{~m}$ above stream level, some $70 \mathrm{~m}$ upstream of Cascadas Chumaceiro and some $200 \mathrm{~m}$ downstream of Cascadas Tovar (Fig. 2). This level probably never encounters flood waters directly, but it is within the zone of foam aerosol generated by the waterfalls (Aubrecht et al., 2012, p.107). 
Like wet calcite speleothems in limestone caves, it can be extremely difficult in the field to estimate whether a sample is still active, and especially in this case, where no active drips are associated with the any of the samples. However, as these silica biospeleothems become altered over time, we observe that they generally change in colour, from pure white to more yellow, as well as in hardness, from $<2$ to $>6$.

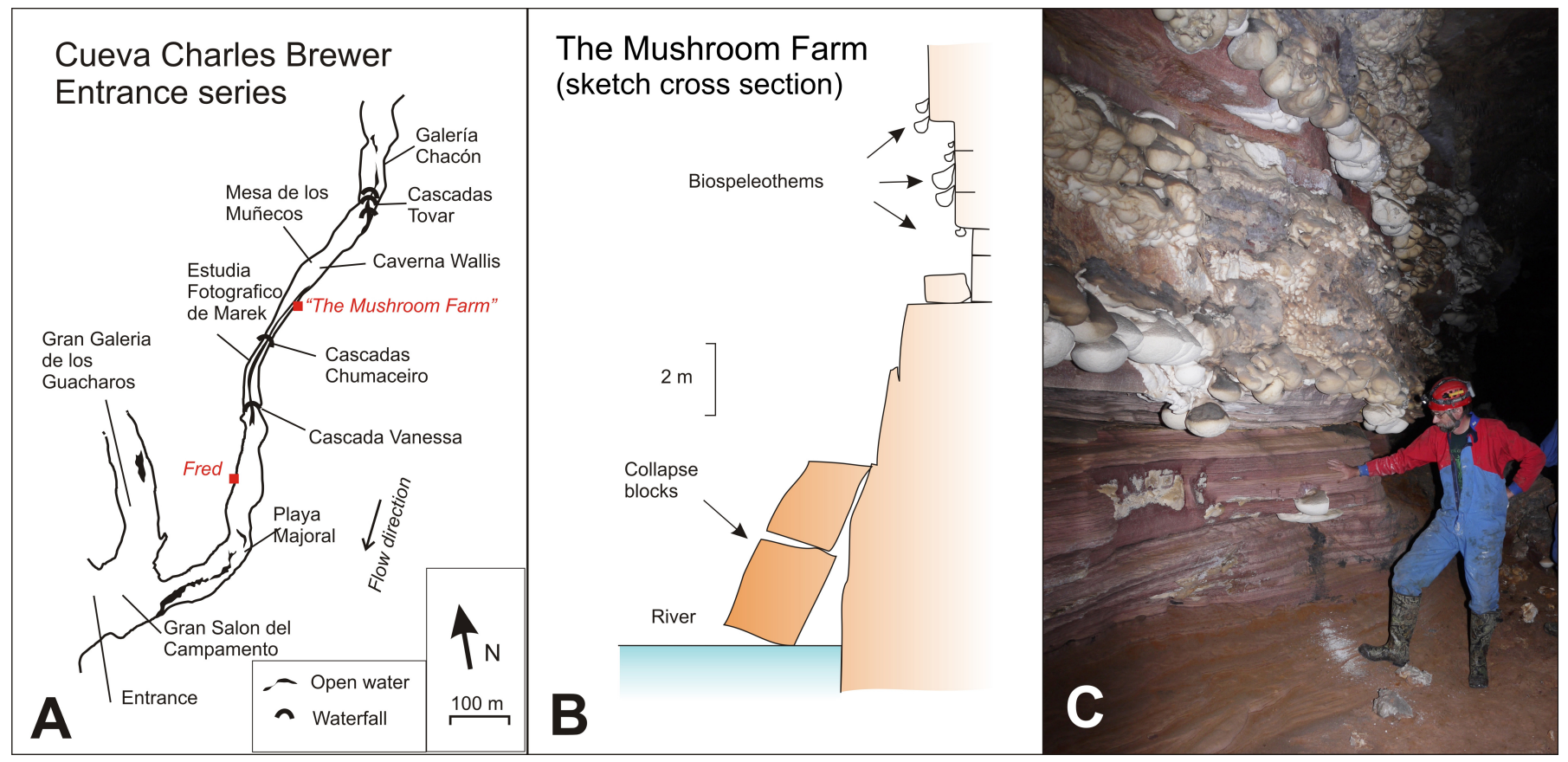

Fig. 2. A) Cueva Charles Brewer, survey of entrance series, showing sampling locations; B) Sketch cross section of the main sampling area, "The Mushroom Farm"; C) Photograph of the Mushroom Farm wall. The figure is pointing to the sample called Sliced Ham.

\section{Trailer Hitch}

This sample, Trailer Hitch (TH, Fig. 3), was chosen because it looked fresh, showed no signs of erosion, had a simple shape (thus was likely to demonstrate a simple growth sequence) and was probably still growing. The site is $\sim 11 \mathrm{~m}$ above stream level, and $\sim 3 \mathrm{~m}$ above the shelf that gave access to these samples. The sample is $6 \times 4 \mathrm{~cm}$, attached to the surface by a $3-\mathrm{cm}$ wide stalk. It grew underneath a slight overhang, but, as with all the biospeleothems, was not associated with any drip point. All samples in the vicinity have the same basic curved shape, the growth layers showing concentric accretion. The core that is exposed in cut section (Fig. 3B) is about $1 \mathrm{~cm}$ wide, of off-white, slightly hardened silica (hardness of 2-3). The outer material is extremely fragile, porous, friable silica (hardness value $<2$, the lowest number available by this method of testing). The diameter from the core to the outer edge along the dated transect is $28 \mathrm{~mm}$.

The external morphology of this sample and others in the vicinity, the internal growth lines and the X-ray image suggest a somewhat complicated history. Figure 3A shows several small "nubs" of white accretion in the vicinity - baby champignons that presumably will develop from their initial simple pimple shape to become like Trailer Hitch. The champignons around Trailer Hitch all have the same basic features: the point of attachment is narrow, accretion occurs preferentially on the downward-facing surfaces and asymmetrically, while the surface facing upwards accumulates a slight dis-coloration from detritus. However, the X-ray image of Trailer Hitch (inset to Fig. 3B) reveals a core of somewhat denser material in a very convoluted shape (white in the image), and the rest of the sample is a uniform grey. The relatively simple growth lines exposed in the section (Fig. 3C) do not appear to follow the convolutions of the core.

The assumption that flood waters probably never reach this shelf is based on the elevation above stream level, the very fragile nature of the samples - they are so delicate that particles slough off with even the most careful of touch - and the absence of evidence for fluvial erosion. The absence of any obvious supply of water (either from drips or from flood waters) implies that the detritus is all air-borne fallout (from aerosol or from fine dust).

The material has exceptionally low uranium content (0.01-0.13 ppm U) and high detrital thorium content relative to the corresponding uranium concentration $\left({ }^{230} \mathrm{Th} /{ }^{232} \mathrm{Th}\right.$ activity ratios are all under 10$)$. The ${ }^{238} \mathrm{U} /{ }^{232} \mathrm{Th}$ activity ratios are low but the extra ${ }^{234} \mathrm{U}$ from the high ${ }^{234} \mathrm{U} /{ }^{238} \mathrm{U}$ values allow us to measure meaningful ages. Assuming continuous growth, the dates show extremely slow growth from $200 \mathrm{ka}$ - marine isotope stage (MIS) 7 - through $\sim 120 \mathrm{ka}$ (MIS 5) and $27 \mathrm{ka}$ (MIS 2-3). All samples have high ${ }^{232} \mathrm{Th}$ relative to $\mathrm{U}$ and so all are adjusted for detrital content. Propagating the growth curves to the outer edge yields $0.7 \mathrm{ka}$ using the non-adjusted dates, and $5.2 \mathrm{ka}$ with the adjusted dates, supporting our interpretation that this sample was still active at the time of collection. With $24 \mathrm{~mm}$ of accretion in $200 \mathrm{ka}$, the average growth rate is only $\sim 130-140 \mu \mathrm{m} / \mathrm{kyr}$.

The core of this sample has only slight secondary silicification, yielding the relatively robust date of $209 \pm 9(201 \pm 13) \mathrm{ka}$. The other two samples used to calculate the growth rate have moderate detrital content, and the adjustment does not significantly 

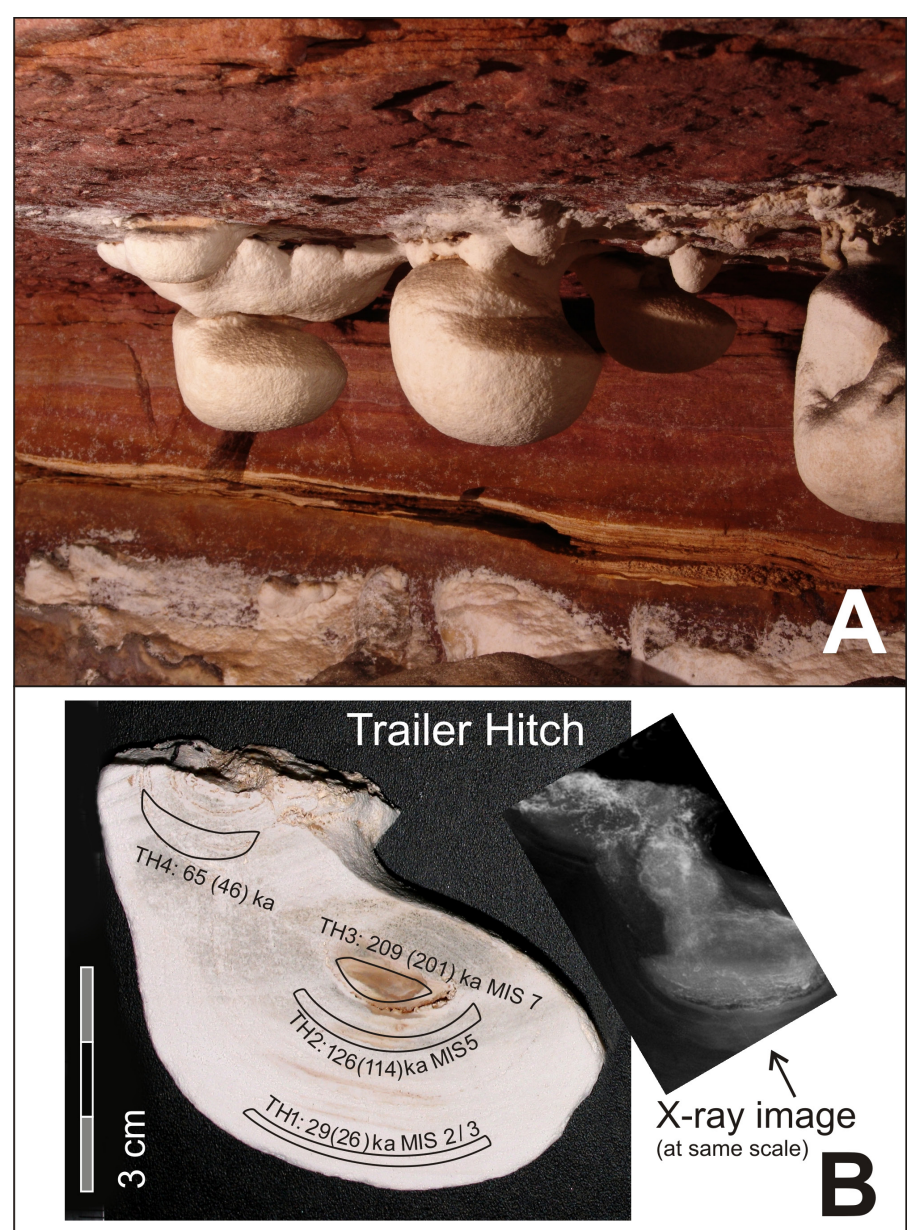

Stalk, point of attachment

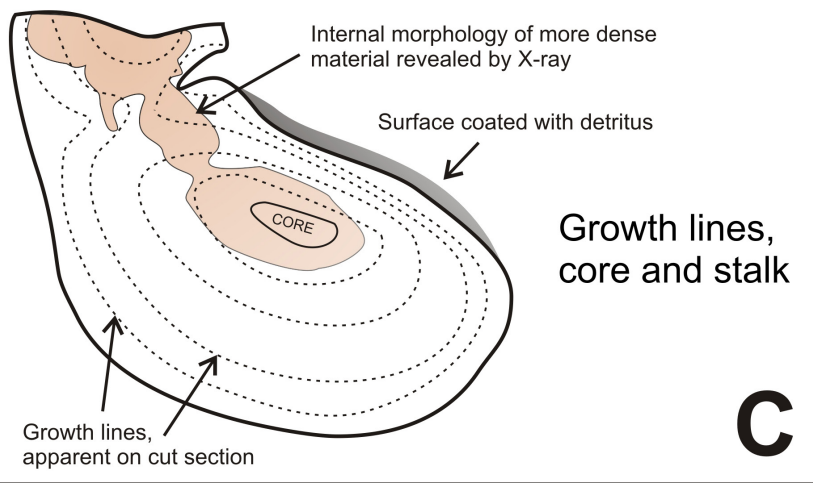

Trailer Hitch dates and marine isotope curve

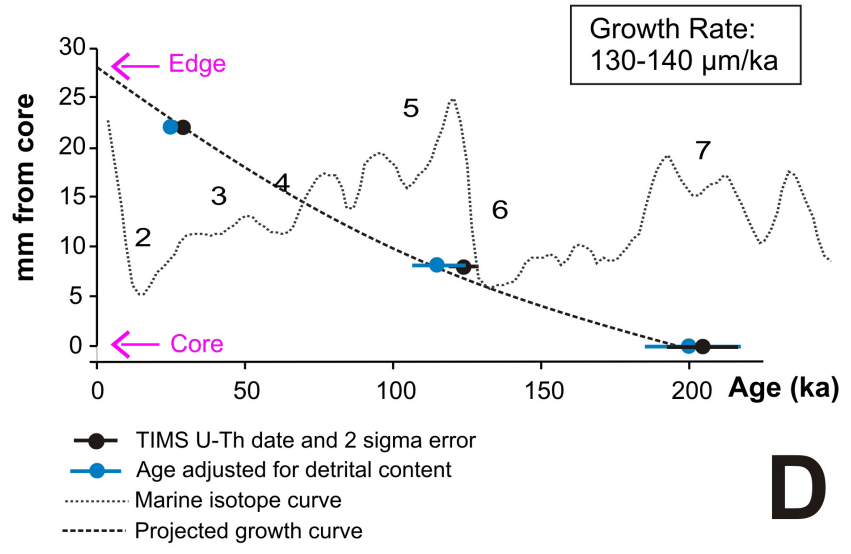

Fig. 3. Trailer Hitch. A) In situ, before sampling; B) Scanned section showing location of dates and, inset, X-ray image; C) Sketch to show features apparent on the cut section. The internal morphology of the more dense core material is added; D) Dates plotted in relation to marine isotope curve (the marine isotope stages are shown as numbers) (Bassinot et al., 1994) and position on transect. alter the growth curve. However, the sample taken close to the stalk, TH4, has the highest detrital content, such that the calculated age of $65 \pm 0.5 \mathrm{ka}$ adjusts to $46 \pm 11 \mathrm{ka}$. This date helps to constrain the growth lines shown in Figure 3C.

\section{Amphora}

Amphora (AMP, Fig. 4) was taken as a companion to Trailer Hitch, but $\sim 15 \mathrm{~m}$ downstream. It is about the same size $(\sim 5 \mathrm{~cm}$ tall), and the same shape, in the same growth position just underneath a small overhang (Fig. 4A), and at about the same elevation above the ledge, but, because of the slight geological dip here (about $1.5^{0}$ to the south) it is about $0.5 \mathrm{~m}$ closer to river. It was also presumed to still be active at the time of sampling. The cut section (Fig. 4B) reveals the concentric growth layers. The X-ray image (inset to Fig. 4B) reveals the internal small, narrow, asymmetric core of more dense material extending from the point of attachment to one side of the sample. A more diffuse region of somewhat more dense material extends a little more towards the centre of the sample (Fig. 4C). Similarly to Trailer Hitch, the majority of Amphora is very soft (hardness <2) and the core a little more yellow and silicified (hardness of 2-3).

The first four dates from the edge inwards are in stratigraphic order and yield an age at the outermost edge of $6.5 \mathrm{ka}$ from non-adjusted dates, and $5.0 \mathrm{ka}$ from adjusted dates, supporting that the sample was likely still active at the time of collection (but with a rather wide $95 \%$ confidence interval). The growth rate for this portion is $350-400 \mu \mathrm{m} / \mathrm{kyr}$.

The dates closer to the core do not continue this stratigraphic trend. AMP 5 at $30 \mathrm{~mm}$ yields only $44 \pm 0.5$ (39 \pm 3$) \mathrm{ka}$. AMP 6, very close to the core and including the narrow cracks (which are not proper hiatuses but may have been sites of water penetration) gives $63 \pm 0.4(62 \pm 1) \mathrm{ka}$. If we assume that the two innermost samples were subject to alteration/silification (AMP 6 is close to the slightly more dense material shown in the X-ray image; Fig. 4B), then the dates do not reflect the time of the original deposition. As a very rough estimate of the age of the core, the growth line propagated to the core suggests that deposition may have started around $120 \mathrm{ka}$. The dates suggest that, although this looks very similar to Trailer Hitch, it probably grew much faster (nevertheless, at only some 2-4 cm growth in $100 \mathrm{kyr}$, all of these biospeleothems seem to have very low growth rates compared with most calcite speleothems).

The next two samples were bigger, but not overtly silicified, champignons: Sliced $\operatorname{Ham}(\mathrm{SH})$, and Ice Cream Bomb (ICB).

\section{Sliced Ham}

Sliced Ham (Fig. 5) is again from the Mushroom Farm site, about 3 m below Trailer Hitch and Amphora (i.e., closer to the water, $\sim 8 \mathrm{~m}$ above the stream), and again chosen because it looked fresh and probably active. The sample is $10 \times 12 \mathrm{~cm}$ in cross section and about $25 \mathrm{~cm}$ wide. It is very white throughout (but with detrital dusting on the upper surface), and, although 

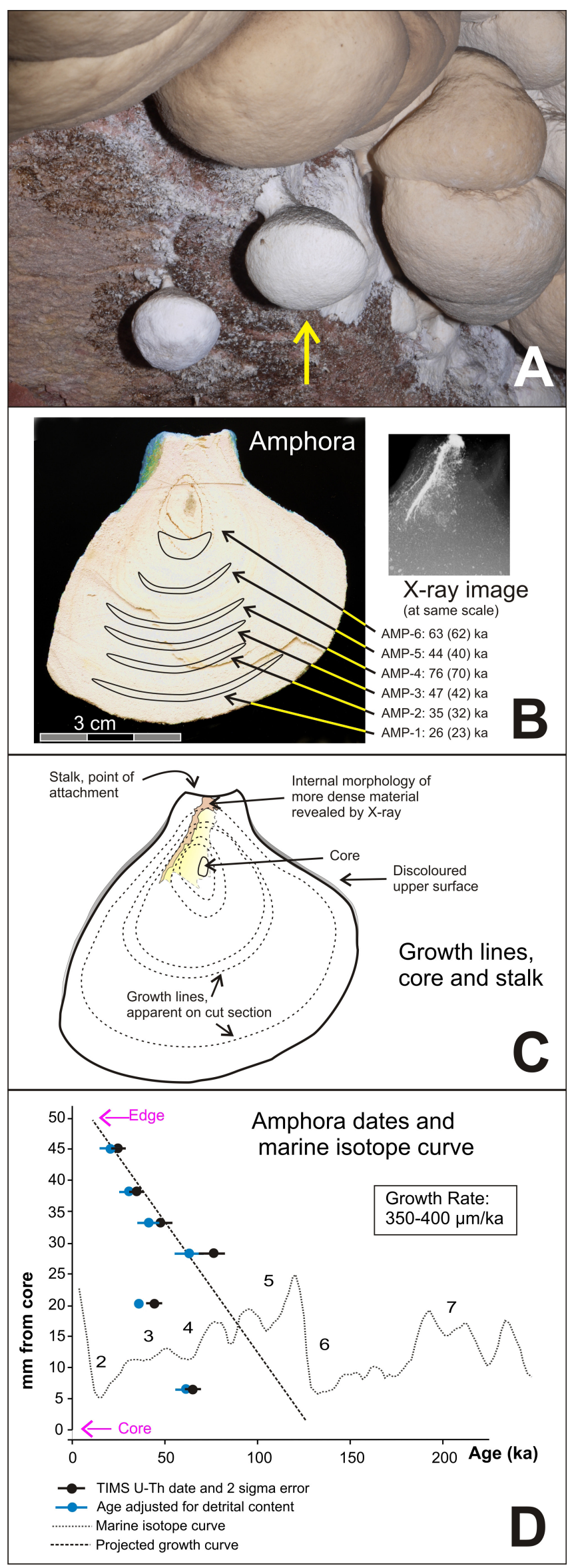

Fig. 4. A) Amphora in situ (marked by the arrow). The stalk can be clearly seen here. The larger champignons above the sample can be seen to have the yellow colour associated with older material that has had secondary silicification; B) Annotated scan of cut section showing dated layers, and, inset, X-ray image; C) Sketch of features apparent on cut section, with internal morphology of dense core added (the obvious dense core shaded in orange and the more diffuse core in pale yellow); D) Dates of Amphora plotted in relation to marine isotope curve. it also has a hardness of $<2$ throughout, is slightly less delicate than the first two. The section was cut a little to the right of the point of attachment. The core does not show any discoloration or silicification. (This sample was too big for the X-ray machine, so details of the internal morphology are not available).

Two of the dating attempts failed completely ( $\mathrm{SH} 2$ and SH6) and SH7, the date closest to the core, is unreliable because the thorium run was of very poor quality, with low counts and short duration. The four dates from the outermost $44 \mathrm{~mm}$ are in stratigraphic
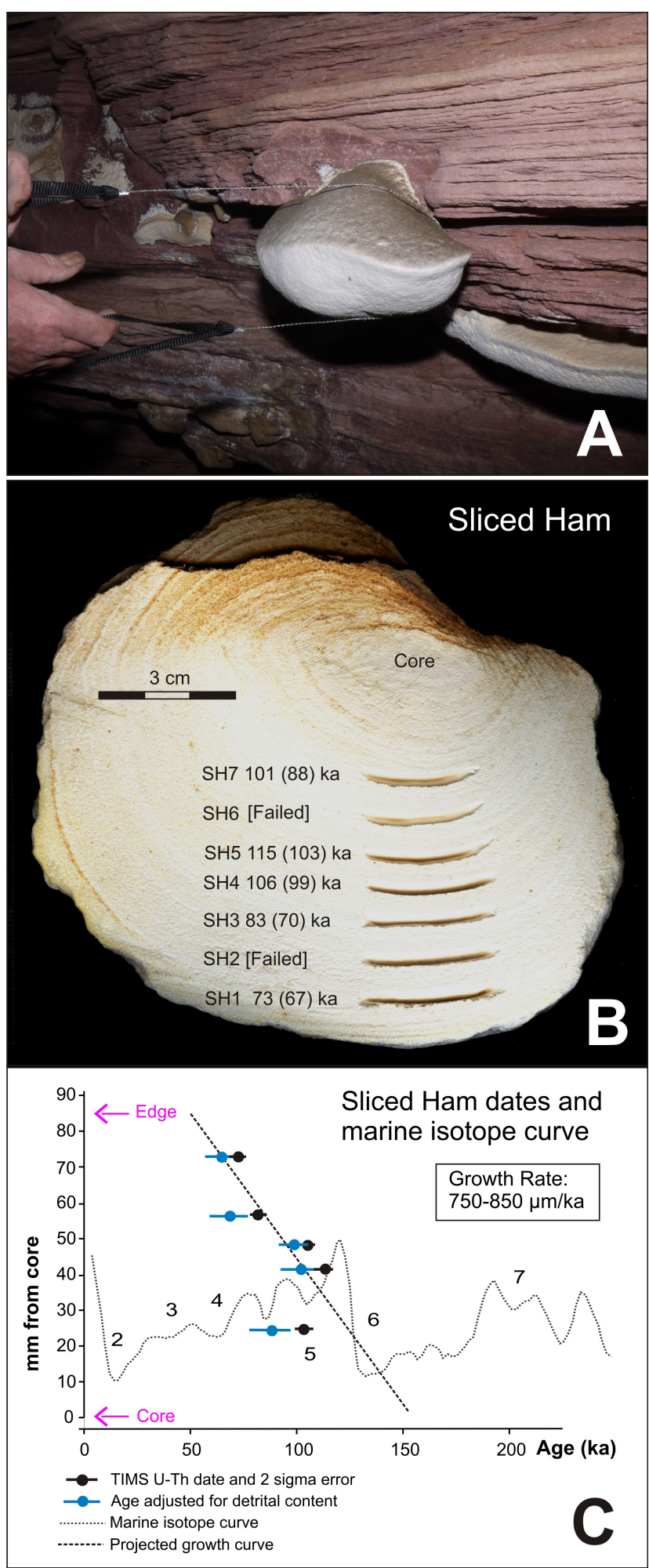

Fig. 5. Sliced Ham. A) In situ, before sampling; B) Annotated scan to show morphology and sampling. Image has been processed to exaggerate colour to reveal growth lines; C) Dates of Sliced Ham plotted on marine isotope curve. 
order, growing from $114 \pm 2.5(102 \pm 9) \mathrm{ka}$ to $73 \pm 0.6$ $(67 \pm 4) \mathrm{ka}$, at a growth rate of $\sim 750-850 \mu \mathrm{m} / \mathrm{kyr}$. The sample therefore apparently stopped growing at $\sim 50$ ka (although in the field it looked just as fresh as the first two samples). Propagating this growth line to the core indicates that the sample probably started to grow at $\sim 155 \mathrm{ka}$.

\section{Ice Cream Bomb}

Ice Cream Bomb (ICB, Fig. 6) was sampled as a companion to Sliced Ham, being about the same size and about the same shape. It grew $\sim 9 \mathrm{~m}$ above stream
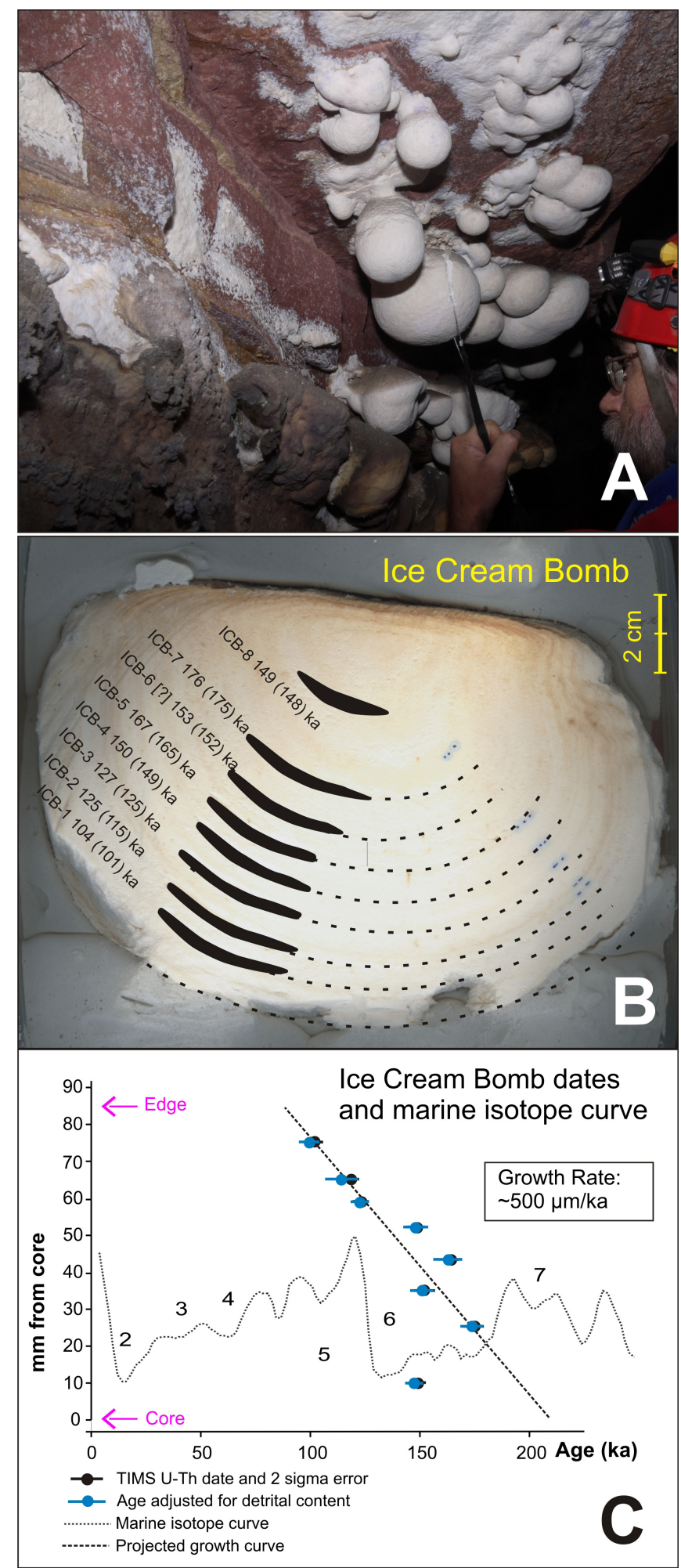

Fig. 6. A) Ice Cream Bomb in situ; B) Annotated section showing dating samples; C) Dates in relation to marine isotope curve. level (below AMP and TH but a metre above $\mathrm{SH}$ ), and is the same hardness as Sliced Ham, <2 throughout, and no core silicification is apparent.

The growth curve propagated (using the first seven dates, omitting ICB-8) gives an estimate of time of initiation at $\sim 210 \mathrm{ka}$, and the sample apparently stopped growing at $\sim 90 \mathrm{ka}$. The growth rate is $\sim 500$ $\mu \mathrm{m} / \mathrm{kyr}$. The date closest to the core, ICB-8, gives a date out of sequence, some $50 \mathrm{kyr}$ younger than the growth curve would indicate, a possible indication of alteration close to the core. The smaller ${ }^{234} \mathrm{U} /{ }^{238} \mathrm{U}$ values relative to other samples may have been a contributing factor in the less reliable ages.

\section{Fallen Angel}

The sample Fallen Angel (FA, Fig. 7) was a large piece (roughly globular, $14 \times 15 \mathrm{~cm}$ ) that had fallen naturally to the floor amid the many collapse boulders, and smashed open. Figure 7 shows that the outermost surface is not an intact layer; rather, the piece had been eroded to expose the internal growth layers. Since the broken surface can be re-fitted together easily and shows no corrosion, we presume that the erosion occurred before the piece fell from the wall. The outer exposed surfaces are all very delicate (hardness of $<2$ ) shedding silica particles at the slightest touch. The growth layers in the outermost couple of $\mathrm{cm}$ are brittle (hardness 2-3) and easily separated. The majority of the piece, from the outermost $2 \mathrm{~cm}$ to the core, is very hard, increasing from a hardness of 4-5 to 7 at the centre. This sample is more yellow than the previous samples. The growth layers are relatively obvious outside of the central, hard mass.

Dating of the relatively hard layer $12 \mathrm{~mm}$ in from the outer edge (FA12) yielded $247 \pm 6$ (235 \pm 12 ) ka. Another sample from the same layer (FA12R), taken to test reproducibility within one layer, yielded $244 \pm 7$ (235 \pm 12$) \mathrm{ka}$ - the same date within error. That the $12 \mathrm{~mm}$ layer gives the same dates implies that both parts of the layer experienced the same history. It would be unlikely for chemical alteration to proceed at the same pace throughout different parts - so the interpretation is that this date does indeed represent the time of deposition.

The sample taken from the very hard and silicified centre of the piece (FA57) yielded a date of $140 \pm 2$ $(117 \pm 16) \mathrm{ka}$. Having established, from the previous four samples, that dates on the porous material tend to be in stratigraphic order, and that growth rates range up to $\sim 800 \mu \mathrm{m} / \mathrm{kyr}$, the core of this sample might be expected to be closer to $\sim 300 \mathrm{ka}$. However, we also noted from experience with the previous four samples, that dates towards the harder cores are sometimes too young to fit the growth curves. We conclude that the process of silicification, which has to postdate the original deposition, compromises the U-Th system such that the date reflects some combination of the original time of deposition and the period over which secondary silica gradually infilled the pores to create this extremely hard material. This suggests that attempts to date material with secondary infill silica are unlikely to be successful - thereby limiting considerably the potential for studying older samples. 

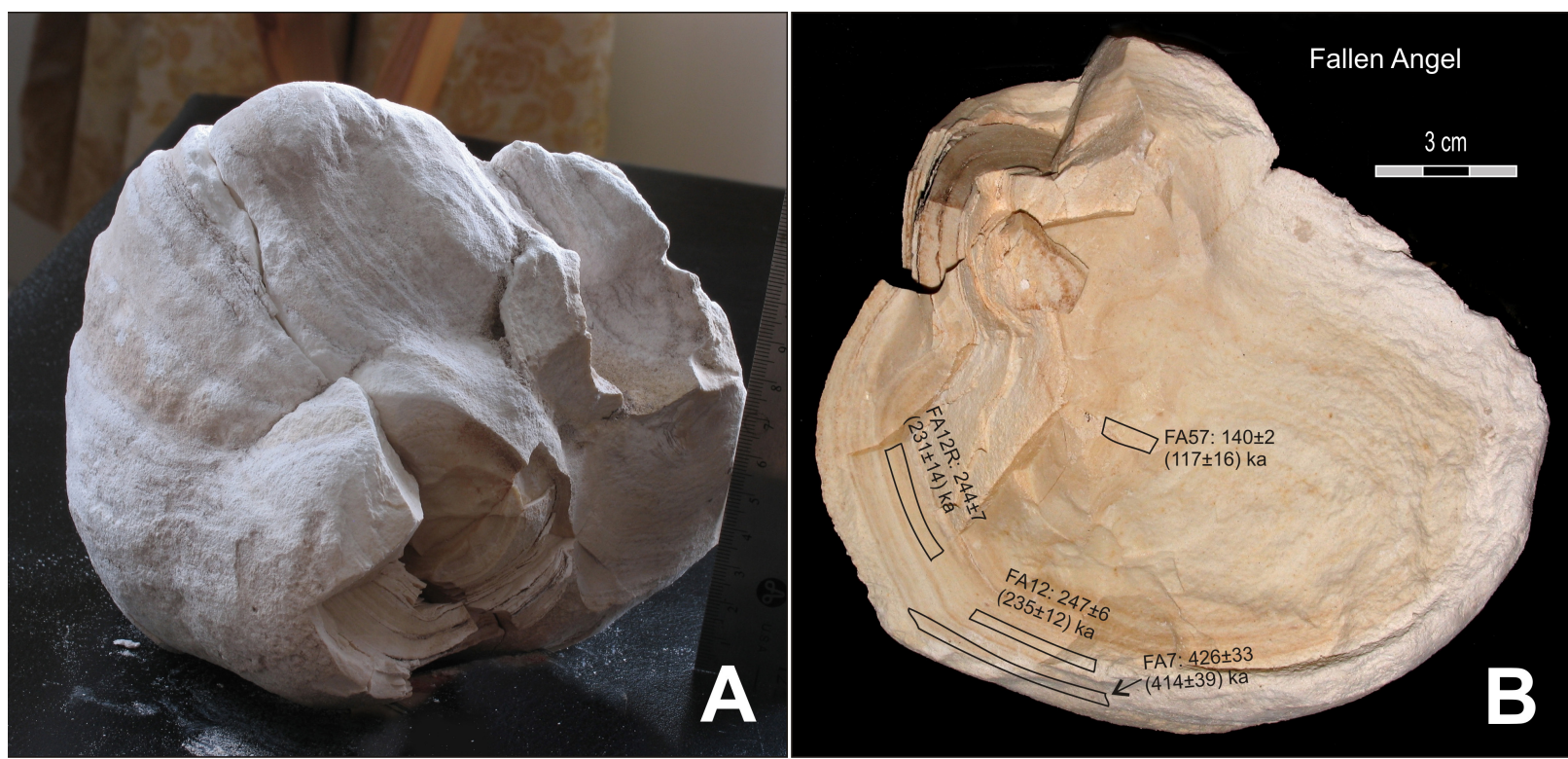

Fig. 7. A) The two pieces of Fallen Angel re-assembled. (Note that this is not in growth orientation: the side on the table was the upper side; B) Dated samples. This sample is naturally more yellow than the previous samples and this scan has no image processing.

The last date attempted was on the very soft outermost layer: FA7 yielded the extremely unlikely age of $426 \pm 33(414 \pm 39) \mathrm{ka}$. This result is harder to explain. The erosion of the outermost material exposing the inner growth layers most likely took place while the sample was still in situ. We have seen several examples of biospeleothems still in place but showing signs of erosion (the small sample to the left of Amphora in Figure 4A is an example). We suggest that chemical alteration after death of the filamentous microbe component (see below), possibly from condensation water, is most likely the cause of this much older-than-expected date.

\section{The Onion}

The Onion (ON, Fig. 8) was picked up in the early explorations of the cave and information about the original site was not recorded. It is the same sample as shown in Aubrecht et al. (2008) Figure 6B, and Aubrecht et al. (2012) Figure 84C (p. 89) but the location of the detrital coating suggests to us that it is similar to the other small champignons and its growth position was as shown in our Figure 8. Much of the outer surface has been damaged through handling over the years: Figure 8 shows the original outer edge (reconstructed from photographs of the piece before damage). It does have a similar overall shape to the other champignons, but the internal structure is more complicated in that it appears to be made of three zones: i) the typical chalky outer peloidal zone; ii) separated by a wavy black "line", the inner, harder, tan-coloured zone; and, finally, iii) the central, very hard, dark, stromatolitic (Aubrecht et al., 2008) zone. The outermost couple of $\mathrm{mm}$ are delicate, with a hardness $<2$, but the next $17 \mathrm{~mm}$ are harder, at 2 -3. Inside the black "line" at $19 \mathrm{~mm}$ the hardness increases to 5-6.

Two dates were done from the outer zone: these were in stratigraphic order, at $68 \pm 1(65 \pm 3) \mathrm{ka}$ and $78 \pm 1(76 \pm 2) \mathrm{ka}$. Two were done from the inner zone: although separated by $12 \mathrm{~mm}$ and several distinct growth layers, these gave exactly the same ages, at $158 \pm 1(156 \pm 2) \mathrm{ka}$ and $158 \pm 1(155 \pm 3) \mathrm{ka}$. Obviously only two dates in good stratigraphic order

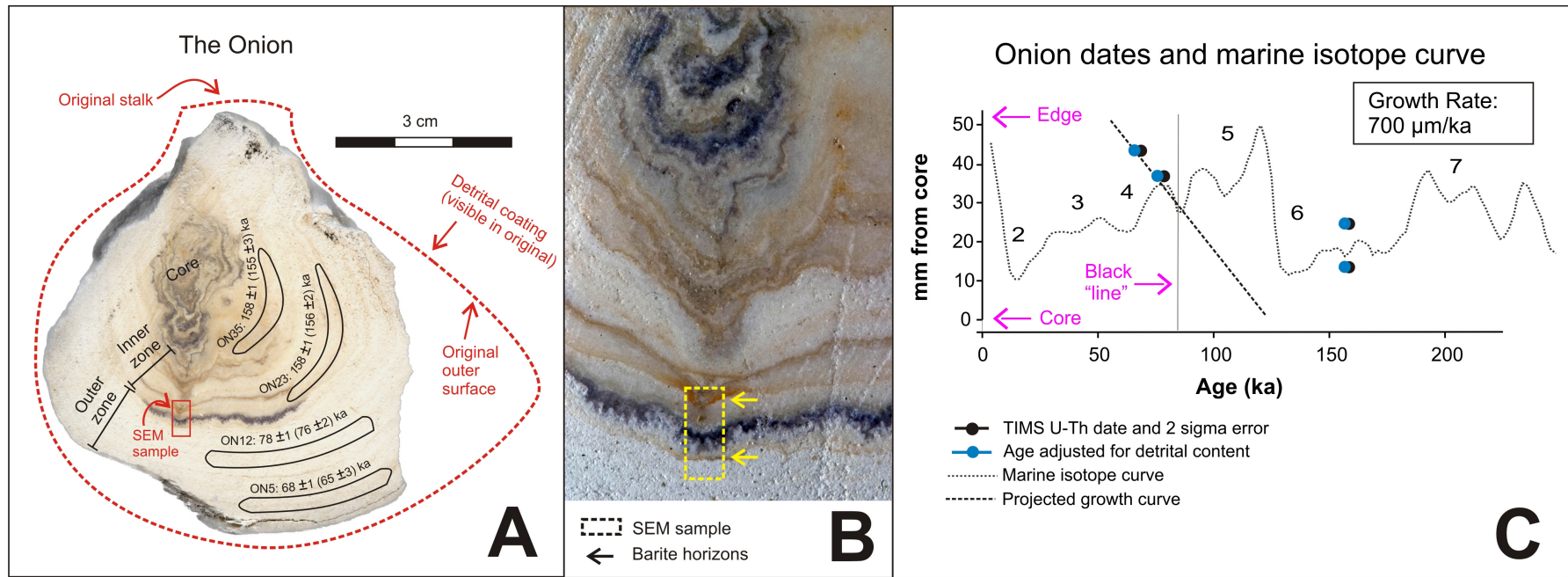

Fig. 8. The Onion. A) Scan of the remains of the original piece with the original outer surface reconstructed, the three zones marked, and the dates. (This sample has more natural colour than the other champignons, so this scan has not been image processed); B) Detail of core and black "line". The piece cut out for SEM is shown and the horizons of barite crystals (see explanation below, in text) shown with arrows; C) Dates in relation to the marine isotope curve. 
does not allow for great confidence in the growth curve, but, if we assume that the growth rate from the outer two dates applied to the whole sample, then the sample stopped growing at $\sim 50 \mathrm{ka}$, started at $\sim 130$ $\mathrm{ka}$, and the black "line occurred $\sim 85 \mathrm{ka}$ in MIS $5 \mathrm{~b}$. However, if we interpret the dates from the silicified region as discussed above (i.e., as the combination of the original deposition time and the timing of the secondary alteration), then the inner part must be older than at least $160 \mathrm{ka}$. The convoluted shape of the inner core suggests that it may have been deposited in stromatolitic form (sensu Aubrecht et al., 2008).

The inner zone appears to have at least four distinct orange bands (Fig. 8A). These may simply be growth lines, but they are strongly reminiscent of liesegang bands - the bands of diagenetic coloration typically seen in sandstones marking migration fronts of alteration. The black "line" is particularly interesting, and its like has not been observed in the other champignon samples. Figure $8 \mathrm{~B}$ shows that it feathers into the overlying porous chalky material underneath it (like moss agate) in a multi-lobed, fractal pattern, indicating that it formed subsequently to the primary accretion.

\section{Fred the Chicken}

The final sample dated for this study is the only one that is not of the champignon type. Fred the Chicken
(FR, Fig. 9) is one of the mushroom shaped, "doll" or "Muñecos" forms (Aubrecht et al., 2008). It was sampled in situ some $200 \mathrm{~m}$ downstream of Cascada Vanessa (Fig. 2A). The gross morphology (Fig. 9A and $\mathrm{B}$ ), that it grows vertically upward (rather than downward) from a narrow stalk and opens out to more bulbous form, and that it has emergent narrow bulbous tips of dark brown hard material, already suggests that this type of speleothem has a different history to the mushroom types. However, the outer, chalky, white material looks the same as the other champignon forms.

The cut section (Fig. 9C) reveals the stromatolitic and complex internal morphology: the point of attachment is a narrow stalk that does not include the darkbrown core material; the core is made up of darkbrown opaline material in tortuous botryoidal forms, which extends upwards into the narrow emergent tip; this is blanketed with layers of paler, more porous peloidal material. Most of the outer surface of Fred is a little harder than the other samples dated (although still less than 2 on the hardness scale), so it was not expected to be young. A few $\mathrm{mm}$ in from the edge, the material has a hardness of 2-3, the tan-coloured inner zone is $4-5$ and the core is $5-6$. Samples for dating included: FR2, $75 \pm 1(62 \pm 8) \mathrm{ka}$, from the white outer zone, FR4 (which failed) and FR5, $124 \pm 2(95 \pm 21) \mathrm{ka}$ from the tan-coloured inner zone, and FRCT, $312 \pm 4$
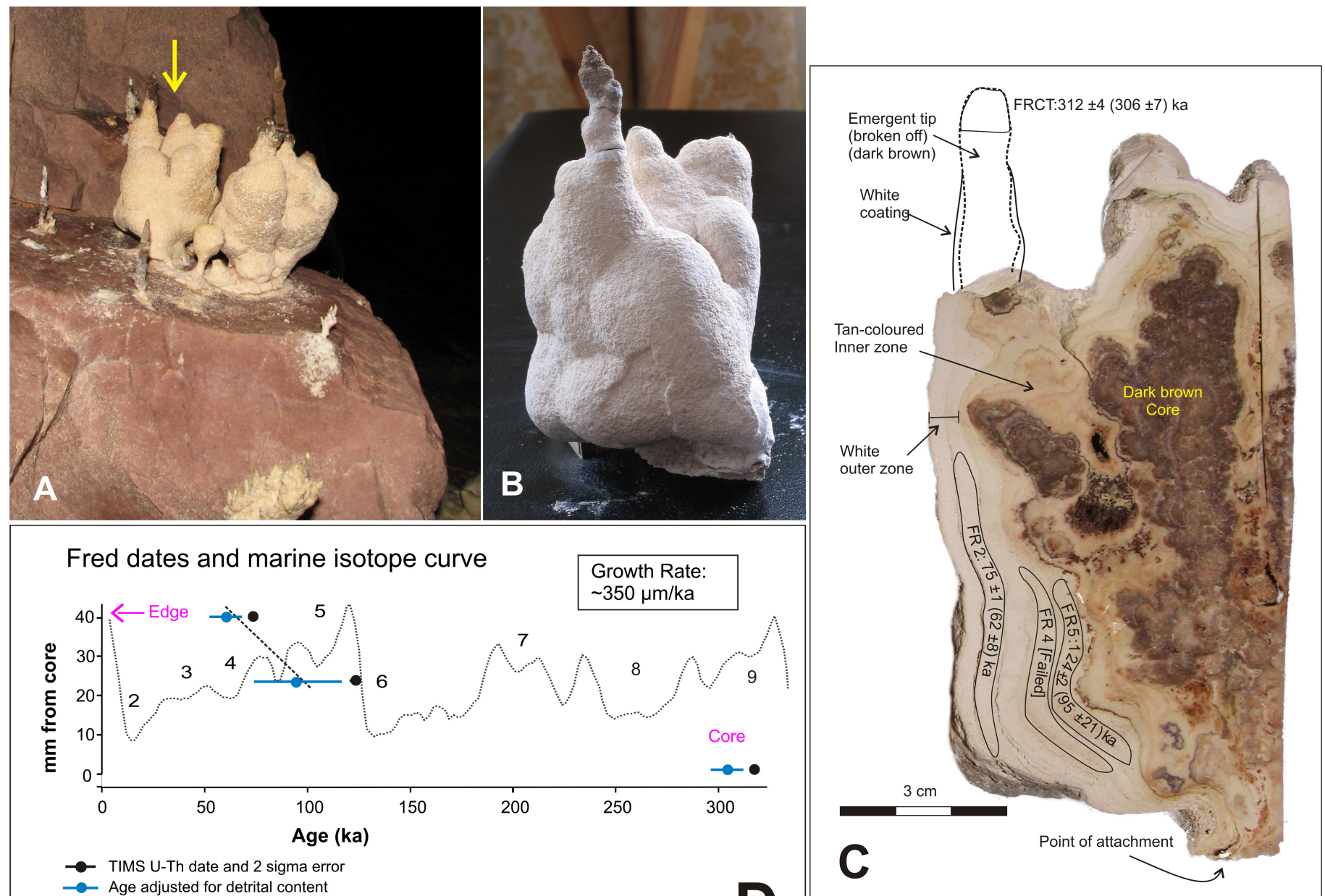

Fred dates and marine isotope curve

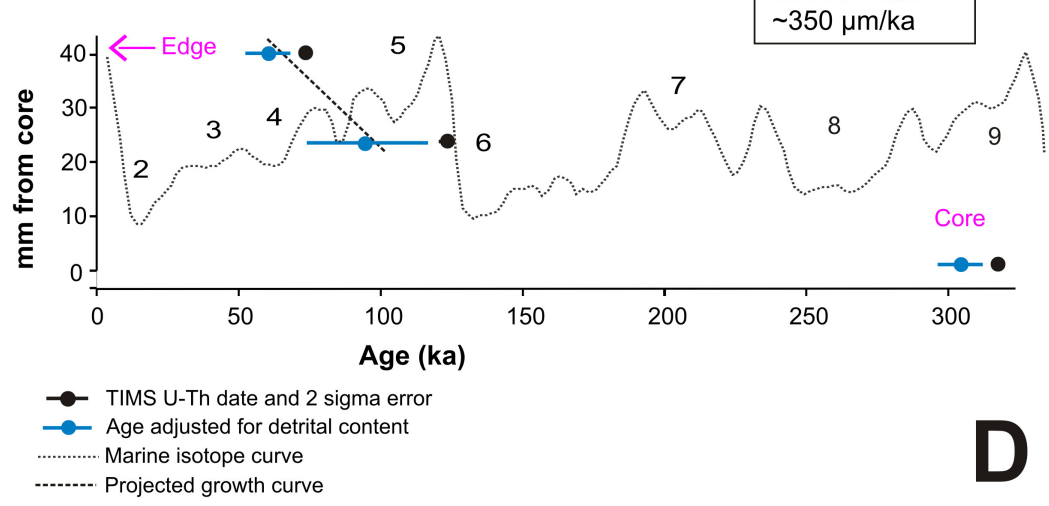

Fig. 9. A) Fred, the Chicken in situ (marked with arrow) growing upwards from the sandstone shelf; B) External appearance of soft, bulbous white peloidal material, but with emergent dark brown tip, of very hard opal; C) Internal morphology showing complex stromatolitic core and sampled layers; D) Dates in relation to marine isotope curve. 
$(306 \pm 7) \mathrm{ka}$, from the tip of the emergent dark-brown core. FR2 and FR5 had high detrital thorium relative to uranium, with ${ }^{230} \mathrm{Th} /{ }^{232} \mathrm{Th}$ activity ratios of $2-3$ (although all were low by normal dating standards, the average for the other samples was 16).

Figure 9D shows the dates in relation to the marine isotope curve. The dates on the outer layers indicate a growth rate of $\sim 300 \mu \mathrm{m} / \mathrm{kyr}$, and that the sample stopped growing at $\sim 50 \mathrm{ka}$ (i.e., MIS 4). The outer layers apparently started to grow somewhere around MIS $5 d$ or $5 e$ (the extreme correction required for FR5 limits precision). Even if we are confident that the date on the core represents the actual time of deposition rather than the time of secondary alteration, it is not clear from the dates whether growth was continuous from the core to the outer edge (at a considerably lower rate), or whether there was a hiatus.

\section{Growth rate and elevation above water level}

The first four samples, all taken from the Mushroom farm, show a significant relationship between elevation above water level and growth rate, in that growth rate is considerably higher closer to water level (Fig. 10), and therefore, we presume, closer to the supply of foam aerosol.

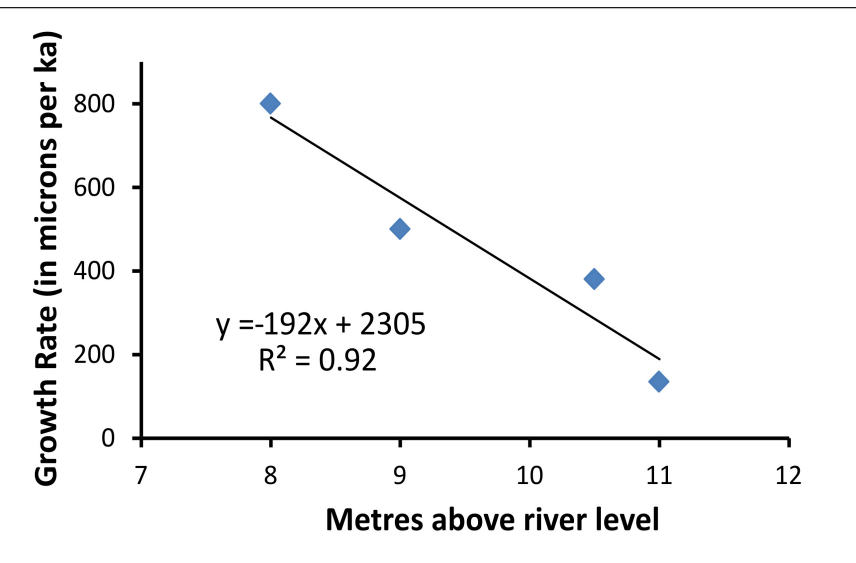

Fig. 10. Growth rates for the Mushroom Farm samples plotted against elevation above water level.

\section{Growth rate and global climatic cycles.}

The growth rates for all the samples, and a slice from each scan to show the morphological details, are plotted together in Figure 11, in relation to the marine isotope curve. Glacial periods are known to have been globally cooler, drier and windier (Bradbury et al., 1981; Hughen et al., 2006; Rull et al., 2010), and thus might be expected to cause reduction or even cessation of deposition. Evidence for this is limited: ON and FR did stop growing in the Early Wisconsin glacial period, but AMP and TH remained active throughout the whole glacial period. Thus, no relationship was found between growth rates and age of sample.

However, the impact of global cycles seems to be apparent in the detrital layers. Detritus accumulates more obviously on the uppermost surfaces of the samples, thus lines of more concentrated detritus can be traced from the upper side around to the main body of the sample. Detritus-rich layers could be caused by an increase in dust supply with a constant growth rate and/or by reduction in growth rate with

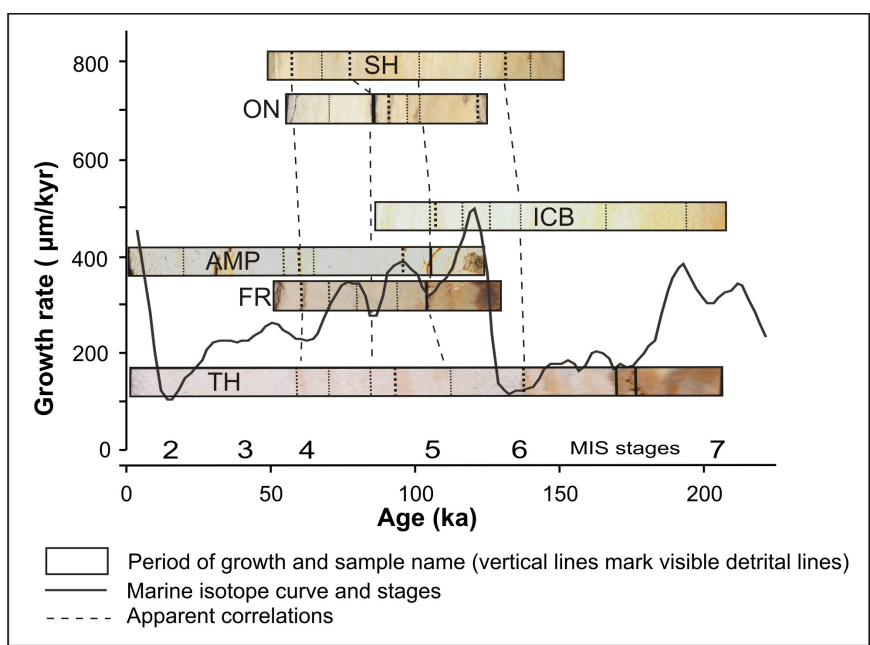

Fig. 11. The six samples growth period and growth rate plotted beside the marine isotope curve. The coloured slices show the features of the samples from edge (paler in colour) to core (usually darker in colour). Visible lines with higher detrital content are marked with vertical dashed lines inside the colour boxes, the thicker the line, the more significant the feature. Apparent correlations of detrital events between samples, and with marine isotope stages are marked with long-dashed lines. Note that the dark-coloured cores of samples AMP and FR, in MIS 5, are not detrital events. Note also that the slower the growth rate, the lesser the confidence with which events are positioned and correlated (e.g., $\mathrm{TH})$. No relationship can be seen between growth rate and Quaternary time, i.e., changing climatic conditions of the glacial-interglacial cycles. However, there does appear to be a reasonable relationship between detrital events and global climate stages, with many of the detrital events associated with cooler, drier phases MIS 6, 5d, 5b, and 4 .

no change in dust supply. Glacial periods are likely to involve both mechanisms (the more arid conditions reducing growth rate and providing more dust).

In Figure 11 the more obvious detritus-rich layers are marked, with lines of varying importance indicative of the density of detritus - the less solid and less thick representing less obvious lines. (Note that the darker colours of the cores are not detrital events). No relationship can be seen between growth rate and Quaternary time, i.e., changing climatic conditions of the glacial-interglacial cycles. However, within the limitations of the dating error, Figure 11 does show that the more obvious detrital layers seem to line up across samples, and with the marine isotope curve, focusing on the four globally cooler periods of MIS $6,5 d, 5 c$, and 4 . Therefore we conclude that there is reasonably good correlation of detrital events and global climate cycles (despite the notable absence, in the only two samples that were still active at the time of collection, of any significant detrital layer associated with MIS 2 glacial period). This result is in keeping with our earlier dating project from this cave where we (Lundberg et al., 2010) correlated dark zones in the sample called Rinon with glacial periods.

\section{Scanning Electron Microscopy}

Studies using scanning electron microscopy (SEM) were used to compare our samples with those studied by Aubrecht et al. (2012), and in order to investigate the processes of primary deposition and secondary silicification.

\section{Materials exposed at outer surfaces}

We looked at two kinds of biospeleothems: the champignon forms, with exposed pure white chalky 
peloidal material on all external surfaces; and the doll forms, generally showing the chalky material only on the lower surfaces, and a hard, dark brown opaline material exposed on the upper branches/tips.

\section{a) Surfaces with chalky, white, peloidal material}

SEM elucidates some of the internal structures of the peloidal material (Fig. 12). At the scale of $\sim 100 \mu \mathrm{m}$, it is made up of loosely-packed peloids (comparable with the images in Aubrecht et al., 2012, p. 100). Higher magnification (Fig. 12B) reveals details of the loosely-packed elongate vermiform fragments, each of which is made up of silica nano-particles ( 0.1-0.2 $\mu \mathrm{m})$ arranged around a central open tube (like curved straws, but made up of agglutinated silica nanoparticles rather than paper; Fig. 12C). The external diameter of the tubules is $1.93 \pm 0.17 \mu \mathrm{m}$, and the
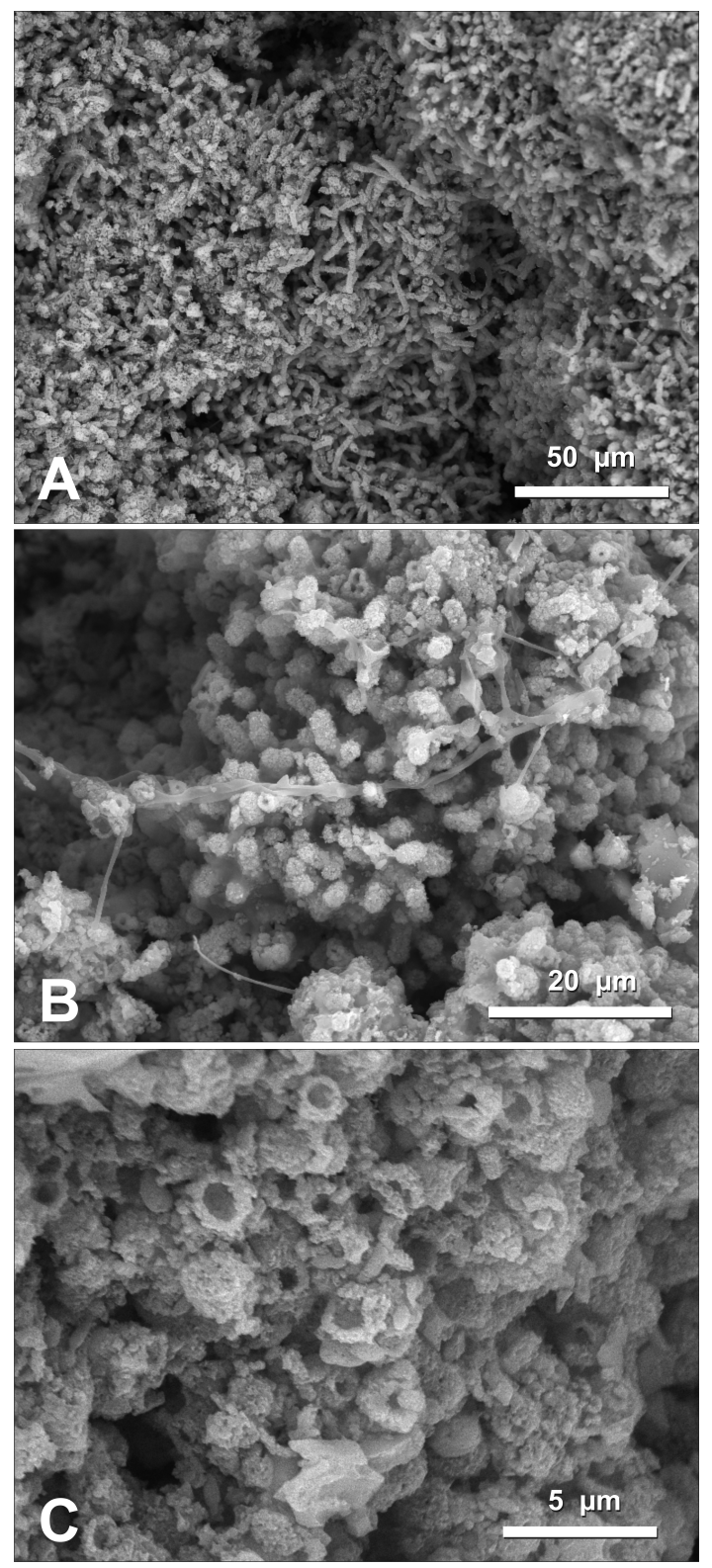

Fig. 12. SEM images. A) General view of the outside surface of Trailer Hitch, showing the loose, porous arrangement of the roughly ovoid peloids (of the order of 100-300 $\mu \mathrm{m}$ long), each made up of aggregates of vermiform tubules; B) Closer view of Trailer Hitch with several filaments (likely fungal) interspersed between the vermiform tubules; C) Detail of the white coating of Fred, showing the hollow tubules made up of silica nano-particles, each of the order of only 0.1-0.2 $\mu \mathrm{m}$, assembled around a cylindrical mould ( $1 \mu \mathrm{m}$ diameter) (presumed to have been filamentous microbes, no longer living). internal diameter is $0.96 \pm 0.30 \mathrm{~m}$. There is no evidence of anything occupying the tubules. Several filaments can be seen to be interspersed throughout the upper $100 \mu \mathrm{m}$ or so. These are probably collapsed fungal filaments (Aubrecht et al., 2008, 2012).

While the peloidal material for both the champignon form and the doll form seem to be about the same, there are subtle differences. In addition to the ubiquitous vermiform tubules, the white peloidal coating on the surface of Fred (the doll form) had more evidence of filaments (likely fungal). The outer layers of Fred also were encrusted to a greater or lesser degree with random fragments such as bits of the tubules, silt particles, and detrital flakes (Fig. 13). These differences may relate to the difference in age of the outer layer rather than a fundamental difference in the process of accretion: Trailer Hitch is probably still actively accreting, but Fred probably stopped accreting $\sim 50 \mathrm{ka}$.

\section{b) Surface with dark brown material}

The surface of the dark brown tip of Fred shows structures not unlike the peloidal material (Fig. 14A), but it is not delicate to the touch, and in detail is more variable than the peloidal material. This porous material is comparable with the images of the "Black Coral" forms imaged by Aubrecht et al. (2012, p. 20). This surface has many areas with no clear features, randomly-shaped quartz grains (presumed to come from arenization of the cave walls - Sauro et al., 2013), filaments and random bits of debris (Fig. 14B), such as parts of diatoms (Fig. 14C). It has a few areas

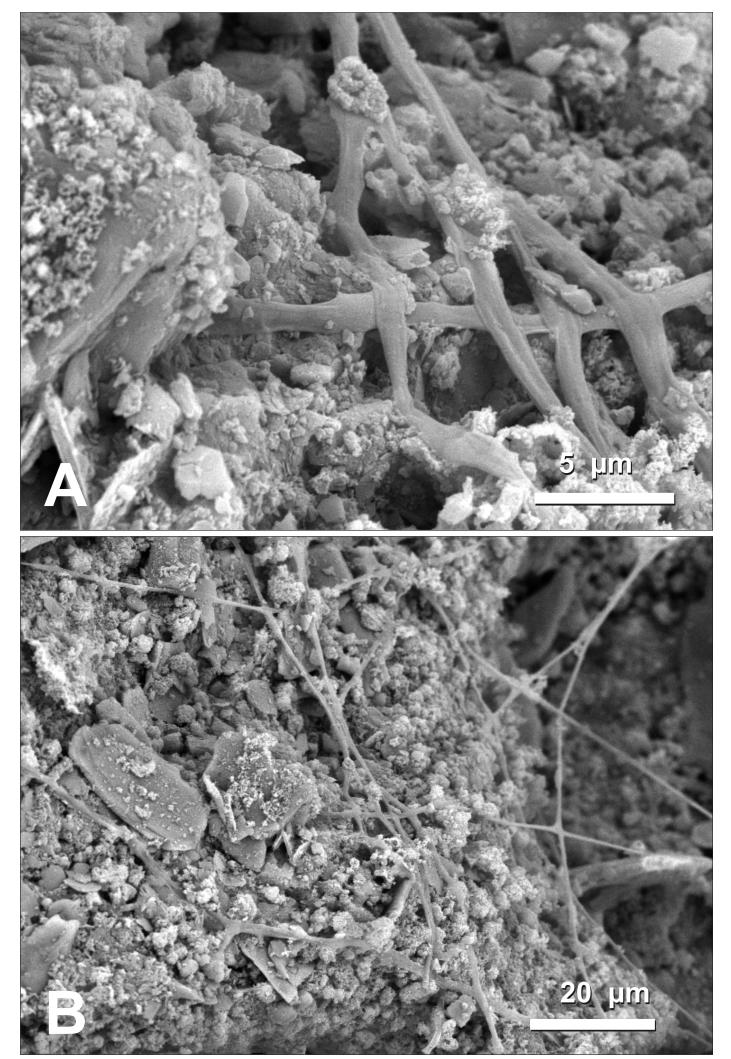

Fig. 13. A) and B). Two views of the white peloidal coating of Fred, showing many filaments (probably fungal hyphae), and what appear to be random fragments of vermiform tubule pieces, silt particles, and detrital flakes stuck together. This is the outer layer of Fred, which probably stopped actively accreting $\sim 50 \mathrm{ka}$, so it may be that more dust than silica has been added since. 
that show vermiform tubules clearly (Fig. 14D) but these are rare. Although very different in external colour, these tubules are not significantly different in dimension from those in the white peloids (external diameter is $1.95 \mu \mathrm{m} \pm 0.70$, and internal diameter is $0.70 \pm 0.21 \mu \mathrm{m}$ : neither diameter is significantly different from the white peloidal tubules, with $p$ of 0.43 and 0.19 respectively).
It is surprising that this surface is located very close to the material from the uppermost $1-5 \mathrm{~mm}$ of the tip of Fred dated at $\sim 300 \mathrm{ka}$, and yet the surface does not look highly silicified. The tubules look about the same as the ones from Trailer Hitch that are presumed to still be actively accreting. It is for this reason that the chronology on the dark-brown, hard, core material must be judged with some wariness.

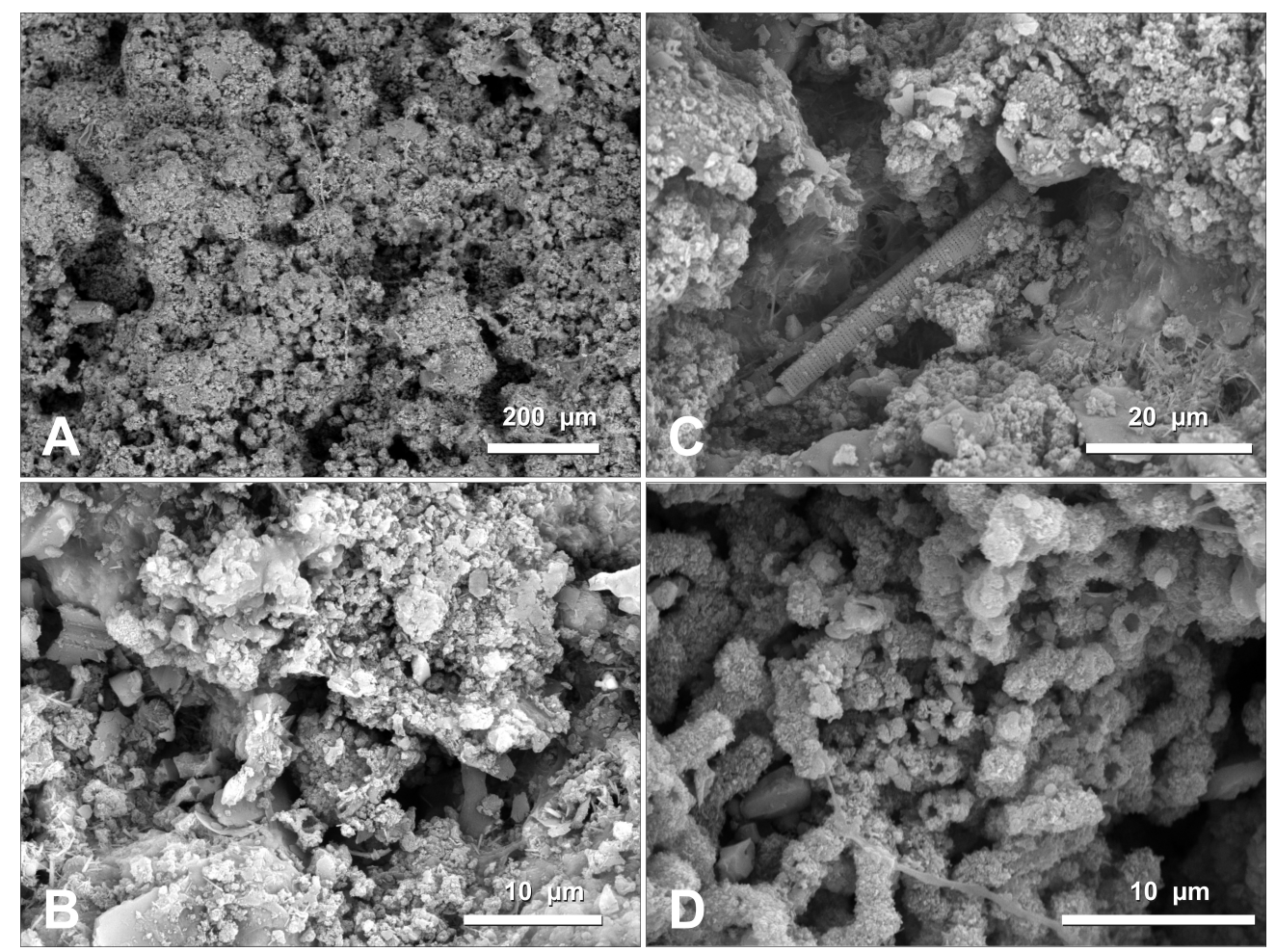

Fig. 14. Outer surface of dark-brown tip of Fred. A) General view of the hard but porous material; B) Region with random detrital(?) fragments, some silt clasts, and small acicular crystals of unknown composition ( 2-4 $\mu \mathrm{m}$ long) scattered around. C) Diatom embedded in detrital(?) particles, a few vermiform tubules, and several of the acicular crystals; D) Region with vermiform tubules.

Material in the inner zones: zones of alteration

a) Process of secondary infilling/silicification

SEM images of the sub-surface peloidal layer of The Onion (the layer dated at $\sim 74 \mathrm{ka}$ ) show that the material is similar to the soft, white peloidal material of Trailer Hitch and Fred (Fig. 15A - compare this with Fig. 12C). It is still porous, but with some evidence of secondary deposition of silica that result in tubules that are still hollow but a little thicker, and the individual nano-particles are not as clear. The deposition appears to be both on the inside and the outside of the tubules - the external diameter of the unaltered peloidal material versus the slightly altered material is $1.93( \pm 0.17)$ and $2.47( \pm 0.30)$ respectively, a significant difference $(p=0.001)$, while the internal diameters are $0.86( \pm 0.30)$ and $0.53( \pm 0.17)$ respectively, also significantly different $(p=0.03)$. The process of silicification produces bulbous surfaces on the tubules, as the original nano-particles are augmented (Fig. 15B). This is the first stage of opal re-crystallization from opal-A into opal-CT (Aubrecht et al., 2008a, 2012). Between the outer and the inner zone of The Onion, induration gradually increases through the tan-coloured inner zone (Fig. 15C shows reduced porosity and less evidence of the original tubules) to the darker-coloured zone with almost complete secondary induration (Fig. 15D).

\section{b) Barite crystals}

Part of the process of alteration appears to include deposition, amidst the peloids, of tabular, bladed crystals that are bright on SEM images (Fig. 16). All the bladed crystals gave an EDS signature of barium sulphate (barite), with $\sim 50 \%$ Ba by weight, $\sim 10 \% \mathrm{~S}$ and $\sim 25 \% \mathrm{O}$. These seem to be restricted in distribution to partings between layers, and we saw them only close to the boundaries of altered and nonaltered zones. The material shown in Figure 16 from the broken tip of Fred - the inside surface of the white coating in contact with the brown core - has lots of bright elongate crystals within the general matrix of peloids and non-descript fragments (including pieces of diatom - Fred was the only sample in which we found diatoms), embedded at random angles. They are up to $\sim 300 \mu \mathrm{m}$ long and $\sim 30 \mu \mathrm{m}$ wide.

The other material in which we observed barite crystals is in the vicinity of the black "line" of The Onion, between the two dates of $\sim 76 \mathrm{ka}$ and $\sim 156 \mathrm{ka}$ (the section extracted for SEM study is shown in Fig 8). The barite is not in the black "line" itself, rather it is concentrated in two horizons: the boundary between the white peloidal material and the black "line"; and along the brown horizon within the tan-coloured material (marked with arrows in Figure 8B). Here the barite is not in well-formed loose crystals - rather it is 


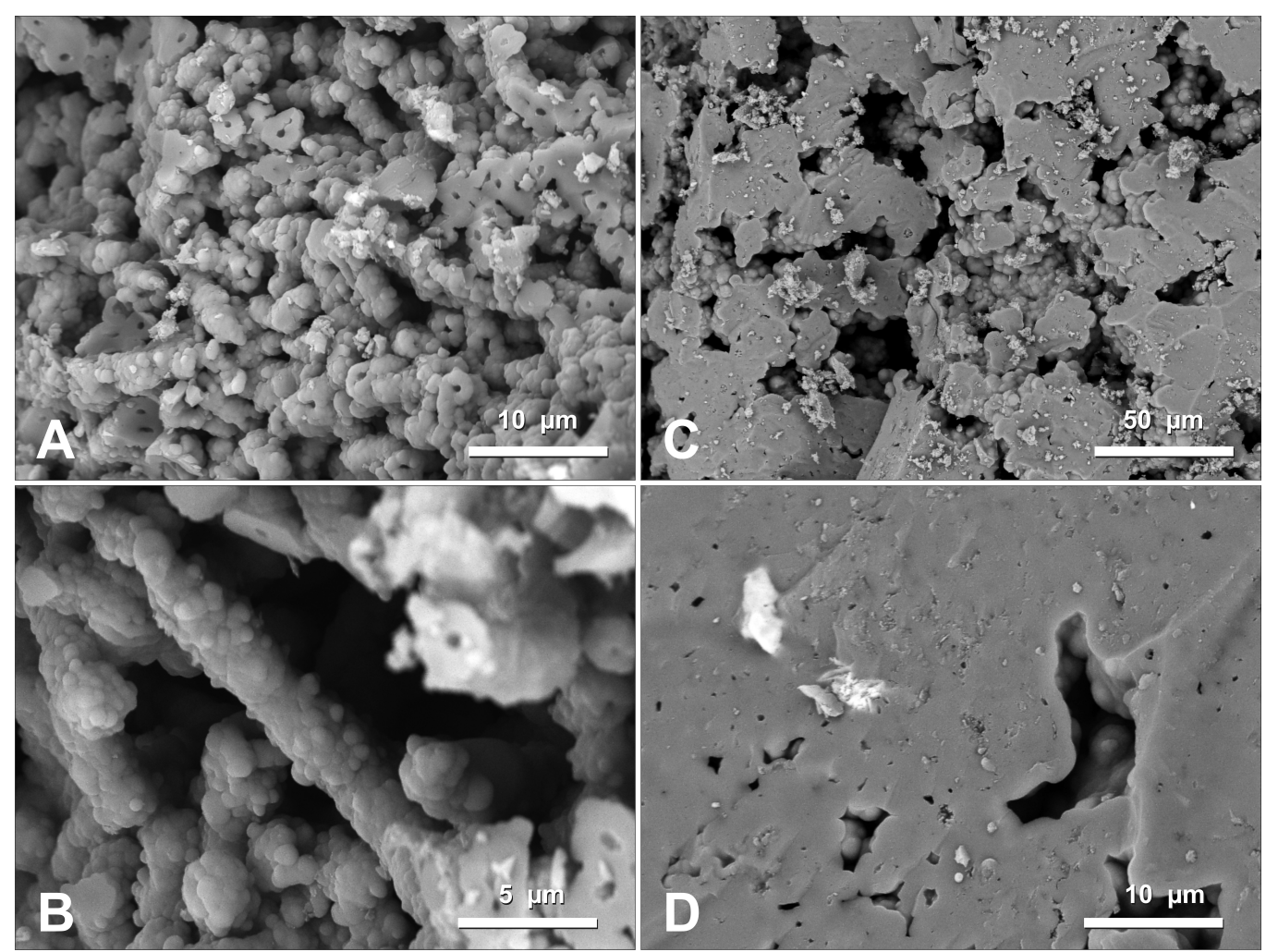

Fig. 15. Sequence of alteration, from The Onion. A) Detail of the white outer zone, made up of porous tubules (of opal-A) but with some evidence of thickening, where the original silica nanoparticles are no longer individually apparent (compare this with Fig. 12C above); B) Detail of the silicification process creating bulbous surfaces (of opal-CT) on the tubules as the space gradually infills; $\mathrm{C}$ ) The harder material of the tancoloured inner zone with fewer pores and barely discernable tubules; D) The dark-coloured material with very little of the original structure discernable (the white patches are barite - see discussion below).

constrained within pores. Figure 17 shows domains of barite crystals scattered about in the pores. Barite is white, but the dark colour of many specimens and these orange-coloured bands in the Onion probably come from small amounts of iron ( $c f$ Hill \& Forti, 1997 , p. 201). The black "line" itself appears to be fully silicified and dense, showing very few features under SEM.

\section{The dark brown core material}

The fully silicified core material shows very little in SEM imaging unless the material is etched first.
This reveals a few remnant pores and something of the original internal complexity (Fig. 18). Aubrecht et al. (2012, p. 93-96) present many images similar to this, of etched stromatolitic core material, and they attribute the shapes to filamentous microbe casts. In Figure 18B the bulbous shapes of the opal-CT spherules inside the pores can be seen. Compare this with the images in Figure $15 \mathrm{~B}$ and $\mathrm{C}$ of the partlysilicified part of The Onion. The process of silicification thickens the tubules, accreting onto the original silica nano-particles and exaggerating variations, eventually joining up into contiguous laminae, of botryoidal form.
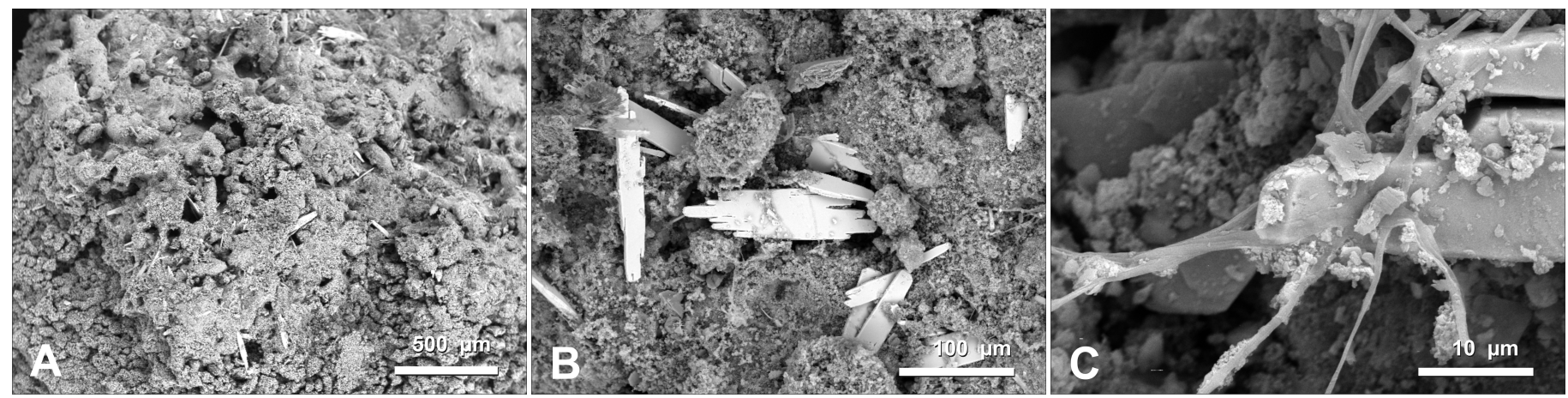

Fig. 16. Fred, the inner surface of the white peloidal material in contact with the brown core tip. A) General view showing the tabular-bladed crystals of barite distributed at random amongst the peloids; B) Detail of the barite crystals; C) Barite crystal amid dust fragments, and bound with filaments.

\section{Trace element Chemistry}

In order to help elucidate the most likely source of material causing accretion of the biospeleothems, we measured minor and trace elements of both the speleothems and potential source material. Since the water supply does not come from cave drips, other sources include the in-cave stream, the foam and associated aerosol created at waterfalls (especially during high water conditions), condensation water, and possibly some ground-water percolating slowly through the rock.

The data on water chemistry from Churi tepui are from Aubrecht et al. (2012) and summarized in Table 1. They noted that water chemistry is not very constant, 


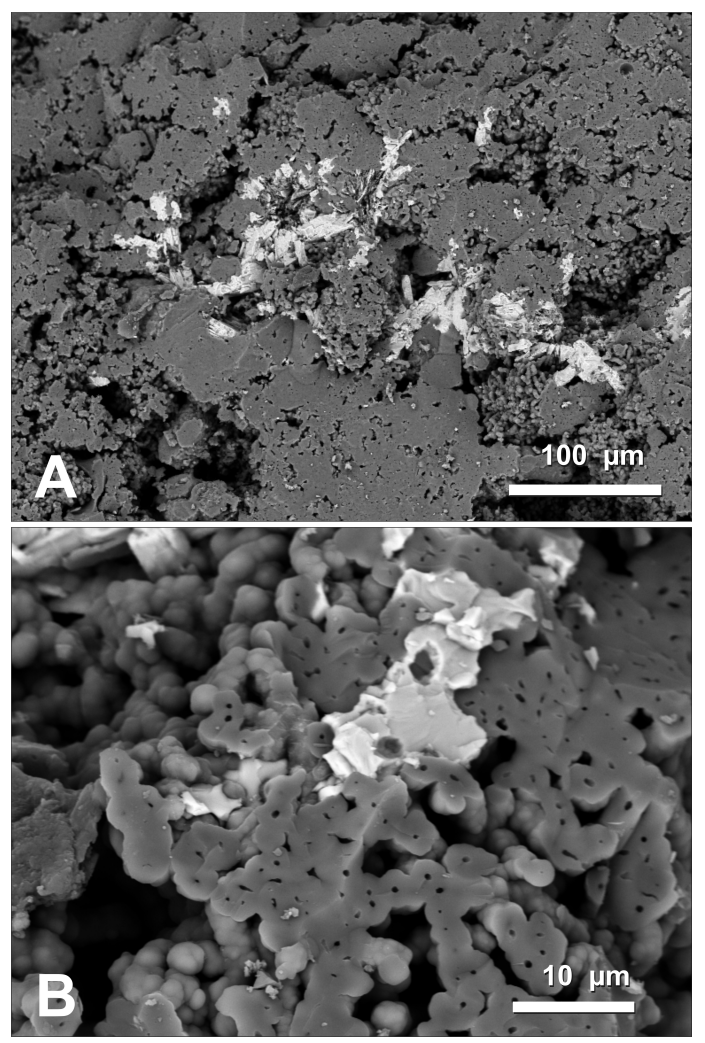

Fig.17. The Onion. A) General view of the barite domains close to the black "line"; B) Detail of the barium sulphate amidst the silicified but still porous material. The original tubules are still clear.

varying with time, season and location (so these few data are simply indicative of general properties). Data from the $\mathrm{CBC}$ underground stream show generally low values for dissolved compounds (for comparison, our analysis of the $\mathrm{CBC}$ underground stream, taken during low flow conditions, yielded $0.40 \mathrm{ppm} \mathrm{Si}$ and $0.03 \mathrm{ppm} \mathrm{Fe}$ ), and dripping water in $\mathrm{CBC}$ (which is generally not associated with biospeleothem growth) has rather higher values.

In order to test for the most likely source of material for the biospeleothems, we sampled the in-cave stream water, and collected the foam left on surfaces since the last flood event, which produced a brown liquid. We could not collect any condensation water, nor could we collect any of the aerosol. We presume that the aerosol must be similar in composition to the stream and the foam (bearing in mind that the foam and aerosol are much more abundant in flood conditions, when rain may flush out the surface swamps, and that the in-cave stream composition in low flow conditions may therefore not be so similar to the foam). The data in Table 1 show that the surface creek and the swamp drainage waters had generally higher values than the cave waters. We also tested the rock and the three types of speleothem material observed during this study - namely the white peloidal material, the pale-yellow silicified material, and the dark core material. Table 2 presents the major components (other than silica) of our samples, expressed as a percentage of the total.

Cluster Analysis on the data in Table 2 (Fig. 19A) separated Foam, Stream and Peloidal Speleothem into one group (with Foam and Peloidal Speleothem closest), and Pale-yellow Silicified Speleothem, Darkbrown Speleothem Core, and Rock into another group



Fig. 18. The dark-brown core material from Fred. A) Without etching, very few features can be seen, other than a few remnant pores;

B) A region etched in HF acid, shows pores and some structures;

C) Detail of etched region - formerly a clump of tubules.

(with Rock and Core closest to each other). Principal Component Analysis confirmed these groupings (Fig. 19B).

These groupings suggest that there might be two sources for the different components of the speleothems. The origin of the peloidal material is most likely to be the aerosol from the foaming stream. This is supported by our observation that growth rates in the Mushroom Farm area seem to be correlated with proximity to water. In addition, Aubrecht et al. (2012, p. 102), on the observation of the ubiquitous fine aerosol and that the majority of the biospeleothems seem to be close to water, suggested that the aerosol may well be an important source. This, however, does not hold for the material with secondary infilling of opal and the dark core material. These would appear to have a source of water that is more characteristic of the rock composition. Looking at the results of the test, reported in Brewer-Carias and Audy (2010), and Aubrecht et al. (2012, p. 99), on potential capillary transportation throughout a section of "doll", we 
Table 1. Summary of potentially relevant water chemistry data from Aubrecht et al. (2012).

\begin{tabular}{|l|c|c|c|c|}
\cline { 2 - 5 } \multicolumn{1}{c|}{} & $\mathbf{p H}$ & Si ppm & Fe ppm & PO $_{4-\mathbf{P}} \mathbf{p p m}$ \\
\hline Underground stream CBC $(\mathrm{n}=5)$ & 2.9 & 0.12 & 0.08 & 0.08 \\
\hline Dripping water CBC $(\mathrm{n}=2)$ & 3.9 & 1.82 & 0.02 & 0.07 \\
\hline Surface creek Churi $(\mathrm{n}=3)$ & 4.1 & 0.27 & 0.13 & 0.10 \\
\hline Swamp Churi $(\mathrm{n}=2)$ & 5.6 & 0.24 & 0.13 & 0.24 \\
\hline
\end{tabular}

see that the dye was easily transported throughout the peloidal material in only 1 day. These capillarity tests showed that the dye travelled from the base vertically upwards and did not bleed sideways, implying non-random, parallel routeways, rather than simple granular porosity. We suggest that the secondary silicification develops as rock-pore-water is drawn from the stalk of the biospeleothem through these routeways. These arenites have considerable variation in porosity, permeability, lithification and hardness (apparent in field observations, and noted in Aubrecht et al., 2012, p. 56-71), and rainfall over the tepuis is very high (3351 mm per year: Galán, 1992), so it would not be a stretch to envisage capillarity in the speleothem slowly drawing pore water from the rock through the material. The implications of these observations are discussed below. Note that we were not able to collect any condensation waters, and thus could not test the hypothesis put forward by Aubrecht et al. (2012, p. 101-103), that condensation waters may also be a source of silica for the speleothems. We presume that the condensed water has acquired its load of solutes mainly from the rock; thus our supposition that rock is one of the sources is still applicable.

Table 2. Data on chemistry expressed as percentage of total (for elements other than silica, which is not measured in the trace elemental analysis package).

\begin{tabular}{|l|c|c|c|c|c|c|c|c|}
\hline \multicolumn{1}{|c|}{ \% Composition (omitting Si) } & $\mathbf{C a}$ & $\mathbf{A l}$ & $\mathbf{N a}$ & $\mathbf{F e}$ & $\mathbf{K}$ & $\mathbf{M g}$ & $\mathbf{B a}$ & $\mathbf{S r}$ \\
\hline Underground Stream & 53.01 & 2.31 & 6.70 & 1.45 & 25.54 & 6.41 & 0.10 & 0.26 \\
\hline Foam & 58.54 & 8.54 & 12.10 & 6.44 & 5.27 & 6.61 & 0.75 & 0.18 \\
\hline Rock & 6.53 & 67.46 & 6.22 & 10.35 & 2.02 & 2.80 & 2.80 & 0.05 \\
\hline Peloidal Speleothem & 66.62 & 17.45 & 4.76 & 0.00 & 3.08 & 6.35 & 2.92 & 1.16 \\
\hline Pale-yellow Silicified Speleothem & 9.88 & 44.46 & 9.39 & 24.70 & 7.90 & 2.96 & 0.13 & 0.07 \\
\hline Dark-brown Speleothem Core & 4.71 & 61.53 & 5.43 & 19.91 & 4.71 & 1.81 & 1.32 & 0.07 \\
\hline
\end{tabular}

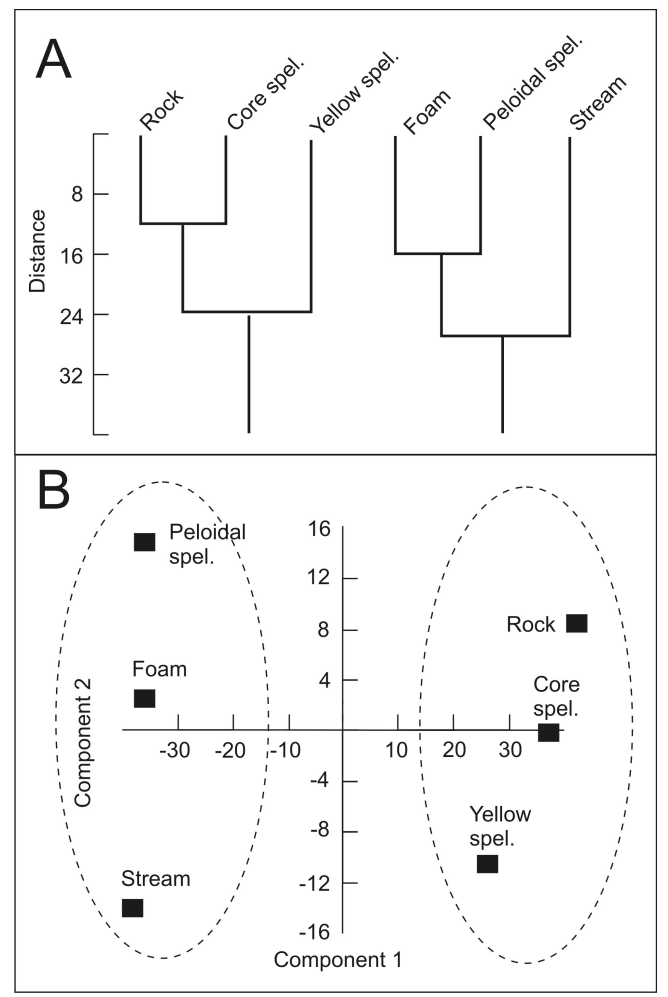

Fig. 19. Results of cluster analysis (A) and principal components analysis (B) on the chemistry data. ("Spel." refers to "speleothem").

\section{DISCUSSION}

The observations on the SEM results along with the chemistry results suggest that there are at least two processes in operation in the production of the biospeleothems studied, and they seem to be sequential in time.
The first process is that the white peloidal material is deposited in the form of nano-particles of silica, probably from the aerosol foam, arranged around narrow filament moulds, which perhaps are, as Aubrecht et al. (2012) discuss, a Nostoc-type cyanobacterial colony. The filamentous microbes grow outwards slowly as the nano-particles smother them, in a stromatolitic manner. The nano-particles making up the peloidal material are of pure white silica. The production of the "black coral" and the brown tips of the "dolls" is probably a similar process of biomediated precipitation onto filamentous microbes, and, since the tubules on the surface of the brown tip of our "doll" sample are of similar morphology and dimension to those in the white peloidal material, the species is likely the same. However, the very different colours and compositions suggest a different source. Perhaps rock dust is mobilised and mixes with the aerosol supply to the "dolls" and "black coral", or else the supply of water to the doll tips comes largely from rock-derived water.

The second process is secondary lining, with opaline material of composition closer to that of the rock, on all available micro-surfaces within the texture of the tubules making up the peloids. This eventually reduces porosity and permeability, closing most of the pores. The primary deposition is clearly a biogenicallymediated process. However, the secondary infilling process is more likely simply a passive, physicochemical one, probably from capillary draw of seepage waters from the rock. From the observations we have made, the dark-coloured core is the final end stage of the secondary infill process, the white, yellow, tan and dark-brown materials all having started with 
the same tubules. However, we note that the dark core material seems to have a much more distinct boundary than the white-yellow-tan gradation, and is usually marked by a distinct edge of very dark, very dense material. Note that this conclusion is supported by SEM observations, and may explain why some of the dates are difficult to interpret. We have observed that infilling events compromise the sequence of dates such that older material with secondary infilling often gives a younger age than material which has not been infilled. However, this does not seem to apply to the darkest material. We have, as yet, dated only two samples of the dark core material, and both are the oldest dates yet produced from these caves (the tip of Fred at $306 \pm 7 \mathrm{ka}$, MIS 9, and the middle of Rinon at $390 \pm 33 \mathrm{ka}$, MIS 11-reported in Lundberg et al., 2010). Obviously more study is warranted. This study was largely focused on the peloidal champignon forms and our results do not necessarily explain the dark stromatolitic materials of the other forms.

There is some evidence that alteration may have a third stage, in which iron- and barium-rich waters make the wavy orange bands (e.g., in The Onion). We have not studied these bands in detail, but, if they are leisegang bands, then this may represent a form of chromatography, the coloured bands marking migrating fronts of iron-rich and barium-rich waters. We did not see any evidence of barite in the core material; if our interpretation is correct, then the migration process requires interconnected pores - thus explaining the absence of barite in the dark dense core material. In Fred, the distribution of barite suggests a migration pathway under the white layer along the impermeable core.

The progression in morphology from a simple white coating of peloidal material on a rock surface to a stalked champignon form (or to any other form) implies focusing of accretion into one spot. We do not know the trigger for increased growth of filamentous microbes in one spot, but Sauro et al. (2013) note that the biospeleothems of Auyan Tepui seem to be associated with edges of rock blocks and suggest that condensation-evaporation processes are mediated by air flow. Whatever the trigger, it is apparent that once the filaments start to grow, attracting their load of silica nano-particles, they continue to elongate outwards. We suggest that outward expansion into globular shapes is a result of simple dichotomous branching of the filaments from the initial narrow starting point, influenced by gravity, and sometimes biased in one direction by air flow. While some of the champignon forms do have a small core of more dense material, there is no evidence that a core is a prerequisite for accumulation of peloidal material. Rather the evidence suggests that the core is a post-depositional feature. The small "nubs" of white accretion beside Trailer Hitch (Fig. 3A) have no suggestion of an initial, thin, pencil-shaped form. The larger samples studied (Ice Cream Bomb, Fallen Angel, Sliced Ham) appear to have no core. Therefore we conclude that champignons do not require an initial stalk. Note that our very limited study of "doll" forms does not allow us to extend this conclusion to any of the other types of speleothem.

The speleothems chosen for this study were relatively young. The dating of these samples indicated considerable variation in the slow growth rates, from $\sim 100 \mu \mathrm{m} / \mathrm{kyr}$ up to $\sim 800 \mu \mathrm{m} / \mathrm{kyr}$. The largest samples we dated were about $12 \mathrm{~cm}$ in diameter; yet considerably larger champignons can be observed in the cave. Assuming the maximum observed growth rate $(800 \mu \mathrm{m} / \mathrm{kyr})$, a sample of $30 \mathrm{~cm}$ diameter is likely to be older than $\sim 375,000$ years old, but the same sample at the more moderate growth rate of 300 $\mu \mathrm{m} / \mathrm{kyr}$ might be a million years old and thus well out of the range of U-Th dating. Of course, conditions such as the rate of supply of aerosol will have changed considerably in that time. The modern elevation above river level was presumably not the same in the past since the river is actively downcutting, and the waterfalls retreating by headward erosion. However, the implication is that the caves may be of considerable age and that some parts of the caves may have been stable for a very long time (obviously, that is not true for the many parts of the cave that are quite delicate, with very fresh fracture surfaces and actively spalling sheets). Many of the speleothems simply fall off under their own weight, some are destroyed by headward erosion of the waterfalls, or by roof/wall collapse, but some of the largest ones (we observed samples of at least a metre in diameter in nearby caves) are potentially extremely old.

Lithification of these biospeleothems may be very complex. Although the peloidal material gave dates in good stratigraphic order, implying that the material has not been altered, porous material obviously can behave chemically as an open system. Secondary cementation is evidence of this. However, secondary dissolution is also possible - see Figure $82 \mathrm{G}$ in Aubrecht et al. (2012, p. 87) - and the resultant dissolution hollow could itself be filled some time later by younger silica cement. Therefore, interpretation of the dates on materials which have experienced secondary infilling must always be treated with caution. In old, silicified material the dates should be proven to be in stratigraphic order (e.g., see Lundberg et al., 2010). Nonetheless, we are now aware that the resultant ages may be more an indication of the timing of alteration rather than the timing of the original deposition. This has implications for the potential of these materials for paleoclimatic reconstructions - in general limiting such potential reconstruction (albeit broad or low-resolution) to the younger, unaltered material.

\section{CONCLUSIONS}

1. U-Th dating of these silica biospeleothems is shown to be successful, but with considerable limitations:

- The U contents are very low;

- The detrital contamination is high relative to $U$ concentration, and causes two problems: The very high ${ }^{232} \mathrm{Th}$ signal compromises the efficiency of the TIMS measurement of the radiogenic thorium 
fraction; and large adjustments may be required to correct the calculated age for presumed initial ${ }^{230} \mathrm{Th}$, with ensuing very high error bars on the resultant age estimates.

- Since growth rates are generally very low, samples need to be taken in very narrow slices, and, since growth layers are sometimes convoluted, it may be difficult to ensure that sampling is truly constrained to the same growth layer.

- Sampling is easy in the soft material but very difficult in the fully silicified cores. Diamond bits need to be of very good quality to ensure that the bit material itself does not contaminate the sample.

- The secondary infill process probably compromises the U-Th dates, unless both the deposition and the alteration were in quick succession or a long time ago. Dating of the fully silicified material may not be reliable unless successive layers can be shown to be in stratigraphic order. Therefore, dating older material requires more replication to increase confidence.

- In practical terms, chemical processing of silica requires the use of facilities set up for use of $\mathrm{HF}$ acid, which may be a limitation in some labs.

2. The results from dating these six samples show that:

- Growth of the champignon forms and of the outermost layers of the doll forms follows simple linear trajectories;

- The unaltered parts generally yield dates in good stratigraphic order;

- Most of the secondary silicification seems to date to older than $\sim 150 \mathrm{ka}$ - implying that the original deposition of these speleothems is older than the $\mathrm{U}-\mathrm{Th}$ dates, and that secondary changes are slow and occur over the timescale of about one glacialinterglacial cycle or more;

- While it was not possible, because of the very slow growth, to pinpoint changes in growth rates, the distribution of detritally-enriched layers seems to correlate well with global climate cycles of the Late Quaternary, in particular the cooler, drier phases of MIS $5 d$ and $5 a$.

3. SEM studies indicate that:

- The white material (of the champignon biospeleothems and the outer layers of the doll forms) is initially deposited as an open porous, peloidal, material which is mechanically very delicate. In detail it is made up of nano-particles of silica that assemble around curved "tubules", which were probably filamentous microbes;

- The uppermost dark-brown surface of the doll form (which looks active, but was not proven to be active by the dating) has similar tubules, but includes many more complex regions with unidentified silicate materials, and a lot more dust;

- The secondary silicification process first cements the nano-particles together to create a more solid "tubule", and then gradually coats every available surface, inside and outside the tubules to create thick bulbous tubes, and then to infill most of the pore spaces with laminated opal, leading eventually to a very dense, very hard material. Evidence of the original tubule morphology is only then made apparent by etching;

- Part of the alteration process is the deposition of barite crystals in pores. Although the barite we observed was in close association with the silicified core material, it is not clear whether the deposition of barite is independent of, or concomitant with, the silicification. The wavy, barium-iron-rich orange bands suggest some form of migration.

4. Chemical analyses suggest that:

- The white peloidal material is distinct from the yellow silicified material and the dark-brown core material, implying that the secondary process of silicification involves a different source;

- Cluster analysis and PCA indicate that foam (and stream water, the source of the foam) is the most likely source for the white peloidal material, while the more coloured speleothem material is closer to rock composition. We suggest that the alteration process occurs from capillary flow, through the porous peloidal material, of rock-derived waters (either rock pore water or condensation water which has dissolved rock).

\section{ACKNOWLEDGEMENTS}

Financing and support was provided by a National Geographic Research and Exploration Grant \#884710 (to JL) and in part by an NSERC grant (to JL). Many thanks to Dr. Natalia Vidal for X-ray imaging, to Lee Groat, UBC, for advice on barite identification, and to two anonymous reviewers.

\section{REFERENCES}

Aubrecht R., Barrio-Amorós C.L., Breure A.S.H., Brewer-Carias C., Derka T., Fuentes-Ramos O.A., Gregor M., Kodada J., Kováčik L., Lánczos T., Lee N.M., Liščák P., Schlögl J., Šmída B. \& Vlček L., 2012 - Venezuelan Tepuis: Their Caves and Biota. Acta Geologica Slovaca Monograph, Comenius University, Bratislava, $168 \mathrm{p}$.

Aubrecht R., Brewer-Carias C., Šmída B., Audy M. \& Kováčik L., 2008a - Anatomy of biologically mediated opal speleothems in the World's largest sandstone cave: Cueva Charles Brewer, Chimantá Plateau, Venezuela. Sedimentary Geology, 203: 181-195.

https://doi.org/10.1016/j.sedgeo.2007.10.005

Aubrecht R., Lánczos T., Gregor M., Schlögl J., Šmída B., Brewer-Carías C. \& Vlček L., 2011- Sandstone caves on Venezuelan tepuis: return to pseudokarst? Geomorphology, 132: 351-365. https://doi.org/10.1016/j.geomorph.2011.05.023

Bassinot F.C., Labeyrie L.D., Vincent E., Quidelleur X., Shackleton N.J. \& Lancelot Y., 1994 - The astronomical theory of climate and the age of the Brunhes-Matuyama magnetic reversal. Earth and Planetary Science Letters, 126: 91-108. https://doi.org/10.1016/0012-821X(94)90244-5 
Bradbury J.P., Leyden B., Salgado-Labouriau M.L., Lewis W.M., Schubert C., Binford M.W., Frey D.G., Whitehead D.R. \& Weibwzahn F.H., 1981 - Late Quaternary environmental history of Lake Valencia Venezuela). Science, 214: 1299-1305.

https://doi.org/10.1126/science.214.4527.1299

Brewer-Carías C., 2005 - Las Espeleotemas de la Cueva Charles Brewer. In: Armando M. (Ed.), Tepuy, Colosos de la Tierra. Fundación Terramar, Altolitho, Caracas, p. 310-327.

Brewer-Carias C. \& Audy M., 2010 - Entrañas del mundo perdido. Corpo Print, Caracas, $291 \mathrm{p}$.

Briceño H.O. \& Schubert C., 1990 - Geomorphology of the Gran Sabana, Guayana Shield, southeastern Venezuela. Geomorphology, 3: 125-141. https://doi.org/10.1016/0169-555X(90)90041-N

Briceño H.O., Schubert C. \& Paolini J., 1990 - Tablemountain geology and surficial geochemistry: Chimantà massif, Venezuelan Guayana Shield. Journal of South American Earth Sciences, 3 (4): 179-194. https://doi.org/10.1016/0895-9811(90)90002-I

Carreño R. \& Urbani F., 2004 - Observaciones sobre las espeleotemas del Sistema Roraima Sur. Boletín de la Sociedad Venezolana de Espeleología, 38: 28-33.

Chacón A.A., Mesa J. \& Mayoral F., 2006 - La Cueva Charles Brewer. Revista FACES, 3 (13): 28-53.

Cheng H., Edwards R.L., Shen C.-C., Polyak V.J., Asmerom Y., Woodhead J., Hellstrom J., Wang YZ., Kong X., Spotl C., Wang X. \& Alexander Jr. E.C., 2013 - Improvements in ${ }^{230}$ Th dating, ${ }^{230} \mathrm{Th}$ and ${ }^{234} \mathrm{U}$ half-life values, and $U-T h$ isotopic measurements by multicollector inductively coupled plasma mass spectrometry. Earth and Planetary Science Letters, 371-372: 82-91. https://doi.org/10.1016/j.epsl.2013.04.006

Cruz F.W. Jr., Burns S.J., Karmann I., Sharp W.D., Vulle M., Cardaso A.O., Ferrari J.A., Dias P.L.S. \& Vlana O.Jr., 2005 - Insolation-driven changes in atmospheric circulation over the past 116,000 years in subtropical Brazil. Nature, 434: 63-65. https://doi.org/10.1038/nature03365

Curtis J.H., Brenner M. \& Hodell D.A., 1999 - Climate change in the Lake Valencia Basin, Venezuela, 12600 yr BP to present. The Holocene, 9: 609-619. https://doi.org/10.1191/095968399669724431

Doerr S.H., 1999 - Karst-like landforms and hydrology in quartzites of the Venezuelan Guyana shield: pseudokarst or "real" karst? Zeitschrift für Geomorphologie, 43: 1-17.

Galán C., 1992 - El Clima. In: Huber O. (Ed.): Chimantá. Escudo de Guayana, Venezuela. Un Ensayo Ecológico Tepuyano. Oscar Todtmann Editores, Caracas, p. 37-52.

Gibbs A.K. \& Barron C.N., 1993 - The Geology of the Guyana Shield. Clarendon Press, Oxford, 246 p.

Hammer O., Harper D.A.T. \& Ryan P.D., 2001 - PAST: Paleontological statistics software package for education and data analysis. Palaeontologia Electronica, 4 (1): 9 p. http://palaeo-electronica.org/2001 1/past/ issue $101 . \mathrm{htm}$

Hill C.A. \& Forti P., 1997 - Cave minerals of the World $\left(2^{\text {nd }}\right.$ Ed.). National Speleological Society, Huntsville. 463 p.

Hughen K.A., Southon J., Lehman S., Bertrand C. \& Turnbull J., 2006 - Marine-derived 14C calibration and activity record for the past 50,000 years updated from the Cariaco basin. Quaternary Science Reviews, 25: 3216-3227.

https://doi.org/10.1016/j.quascirev.2006.03.014

Ivanovich M., Latham A.G. \& Ku T.-I., 1992 - Uraniumseries disequilibrium applications in geochronology. In: Ivanovich M. \& Harmon R.S. (Eds.), Uraniumseries disequilibrium: Applications to earth, marine and environmental sciences ( $2^{\text {nd }}$ Ed.). Oxford, Clarendon Press, p. 62-89.

Lundberg J., Brewer-Carías C. \& McFarlane D.A., 2010 - Preliminary results from U-Th dating of glacialinterglacial deposition cycles in a silica speleothem from Venezuela. Quaternary Research, 74: 113-120. https://doi.org/10.1016/j.yqres.2010.03.005

Mecchia M. \& Piccini L., 1999 - Hydrogeology and $\mathrm{SiO}_{2}$ geochemistry of the Aonda Cave system (Auyantepui, Bolivar, Venezuela). Boletin de la Sociedad Venezolana Espeleología., 33: 1-11.

Nogué S., Rull V., Montoya E., Huber O. \& VegasVilarrúbia T., 2009 - Paleoecology of the Guayana Highlands (northern South America): Holocene pollen record from the Eruoda-tepui, in the Chimanta massif. Palaeogeography, Palaeoclimatology, Palaeoecology, 281: 165-173.

https://doi.org/10.1016/j.palaeo.2009.07.019

Pennington R.T., Credo D.E. \& Pendry C.A., 2000 Neotropical seasonally dry forests and Quaternary vegetation changes. Journal of Biogeography, 27: 261-273.

https://doi.org/10.1046/j.1365-2699.2000.00397.x

Piccini L. \& Mecchia M., 2009 - Solution weathering rate and origin of karst landforms and caves in the quartzite of Auyan-tepui (Gran Sabana, Venezuela). Geomorphology, 106: 15-25.

https://doi.org/10.1016/j.geomorph.2008.09.019

Piccini L., 1995 - Karst in siliceous rock: karst landforms and caves in the Auyántepui massif (Est. Bolivar, Venezuela). International Journal of Speleology, 24: 41-54. https://doi.org/10.5038/1827-806X.24.1.2

Rull V., 2004 - Biogeography of the "Lost World": a palaeoecological perspective. Earth Science Reviews, 67: 125-137.

https://doi.org/10.1016/j.earscirev.2004.02.004

Rull V., 2005 - Vegetation and environmental constancy in the Neotropical Guayana Highlands during the last 6000 years? Review of Palaeobotany and Palynology, 135: 205-222.

https://doi.org/10.1016/j.revpalbo.2005.03.008

Rull V., Abbott M.B., Vegas-Vilarrúbia T., Bezada M., Montoya E., Nogué S. \& González C., 2010 Paleoenvironmental trends in Venezuela during the last glacial cycle. In: Sánchez-Villagra M.R., Aguilera O.A. \& Carlini A.A. (Eds.), Urumaco and Venezuelan palaeontology: The fossil record of the Northern Neotropics. Life of the past. Bloomington, Indiana University Press, p. 52-83.

Santos J.O.S., Potter P.E., Reis N.J., Hartmann L.A., Fletcher I.R. \& McNaughton N.J., 2003 - Age, source, and regional stratigraphy of the Roraima Supergroup and Roraima-like outliers in northern South America based on $\mathrm{U}-\mathrm{Pb}$ geochronology. Geological Society of America Bulletin, 115: 331-348. https://doi.org/10.1130/0016-7606(2003)115\%3C03 31:ASARSO $\% 3 E 2.0 . \mathrm{CO} ; 2$

Sauro F., 2014 - Structural and lithological guidance on speleogenesis in quartz-sandstone: Evidence of the arenisation process. Geomorphology, 226: 106-123. https://doi.org/10.1016/j.geomorph.2014.07.033

Sauro F., Lundberg J., De Waele J., Tisato N. \& Galli E., 2013 - Speleogenesis and speleothems of the Guacamaya Cave, Auyan Tepui, Venezuela. In: Proceedings of the 16th International Congress of Speleology, Brno, 3: 298-304.

Schubert C. \& Fritz P., 1985 - Radiocarbon ages of peat, Guayana Highlands (Venezuela). Naturwissenschaften, 72: 427-429.

https://doi.org/10.1007/BF00404884 
Van der Hammen T. \& Hooghiemstra H., 2000 - Neogene and Quaternary history of vegetation, climate and plant diversity in Amazonia. Quaternary Science Reviews, 19: $725-742$.

https://doi.org/10.1016/S0277-3791(99)00024-4
Zinck J.A. \& Huber O. (Eds.), 2011 - Peatlands of the Western Guayana Highlands, Venezuela, Ecological Studies 217, Springer-Verlag Berlin Heidelberg, 295 p. https://doi.org/10.1007/978-3-642-20138-7

Appendix Table A1. U-Th concentrations, isotope ratios, and dates.

\begin{tabular}{|c|c|c|c|c|c|c|c|c|c|}
\hline Sample & Age (ka) \pm 2 s & $\begin{array}{c}\text { Age ka (adj) } \\
\pm 2 \mathrm{~s}\end{array}$ & $\begin{array}{c}{ }^{238} \mathrm{U} \text { ppm } \\
( \pm 2 \mathrm{~s})\end{array}$ & $\begin{array}{c}{ }^{232} \text { Th ppm } \\
( \pm 2 \mathrm{~s})\end{array}$ & $\begin{array}{c}{ }^{230} \mathrm{Th} /{ }^{234} \mathrm{U} \\
( \pm 2 \mathrm{~s})\end{array}$ & $\begin{array}{c}{ }^{230} \mathrm{Th} / \\
{ }^{238} \mathrm{U}( \pm 2 \mathrm{~s}) \\
\end{array}$ & $\begin{array}{c}{ }^{234} \mathrm{U} /{ }^{238} \mathrm{U} \\
( \pm 2 \mathrm{~s})\end{array}$ & $\begin{array}{c}{ }^{230} \mathrm{Th} / \\
{ }^{232} \mathrm{Th}( \pm 2 \mathrm{~s}) \\
\end{array}$ & $\begin{array}{c}{ }^{234} \mathrm{U} /{ }^{238} \mathrm{U} \\
\text { initial }( \pm 2 \mathrm{~s})\end{array}$ \\
\hline AMP1 & $26.1+0.3,-0.3$ & $23.4+1.7,-1.7$ & $0.0309(3)$ & $0.0143(1)$ & $0.219(3)$ & $1.068(13)$ & $4.880(52)$ & $7.00(7)$ & $5.18(6)$ \\
\hline AMP2 & $35.1+0.3,-0.3$ & $31.8+2.0,-2.0$ & $0.0095(1)$ & $0.0065(1)$ & $0.286(2)$ & $1.702(22)$ & $5.945(65)$ & $7.48(5)$ & $6.46(7)$ \\
\hline AMP3 & $47.1+0.6,-0.6$ & $42.3+3.0,-3.1$ & $0.0168(2)$ & $0.0143(1)$ & $0.369(4)$ & $1.790(27)$ & $4.855(69)$ & $6.40(6)$ & $5.40(7)$ \\
\hline AMP4 & $76.4+1.0,-1.0$ & $69.8+4.4,-4.5$ & $0.0189(2)$ & $0.0183(1)$ & $0.542(5)$ & $2.100(22)$ & $3.877(32)$ & $6.58(5)$ & $4.57(4)$ \\
\hline AMP5 & $44.0+0.5,-0.5$ & $39.6+2.7,-2.8$ & $0.0226(2)$ & 0.0160 & $0.347(3)$ & $1.550(16)$ & $4.462(47)$ & $6.64(4)$ & $4.92(5)$ \\
\hline AMP6 & $63.0+0.4,-0.4$ & $61.7+1.0,-1.1$ & $0.2417(12)$ & $0.0533(5)$ & $0.467(2)$ & $1.983(8)$ & $4.243(8)$ & $27.31(27)$ & $4.87(1)$ \\
\hline $\mathrm{SH} 1$ & $73.1+0.6,-0.6$ & $66.8+3.9,-4.0$ & $0.0403(2)$ & $0.0215(1)$ & $0.516(3)$ & $1.185(7)$ & $2.299(10)$ & $6.73(4)$ & $2.60(1)$ \\
\hline SH3 & $82.7+1.1,-1.1$ & $69.8+7.9,-8.4$ & $0.0186(2)$ & $0.0203(1)$ & $0.565(5)$ & $1.323(15)$ & $2.340(21)$ & $3.68(3)$ & $2.69(2)$ \\
\hline $\mathrm{SH} 4$ & $106.5+2.0 .-2.0$ & $99.1+5.8,-6.0$ & $0.0228(1)$ & $0.0157(1)$ & $0.674(8)$ & $1.613(19)$ & $2.394(13)$ & $7.10(8)$ & $2.88(2)$ \\
\hline SH5 & $114.8+2.4,-2.4$ & $102.6+8.8,-9.2$ & $0.0231(2)$ & $0.0243(1)$ & $0.705(9)$ & $1.589(22)$ & $2.255(37)$ & $4.60(3)$ & $2.74(4)$ \\
\hline SH7 & $101.0+1.6,-1.6$ & $88.4+8.3,-8.8$ & $0.0189(1)$ & $0.0208(1)$ & $0.650(7)$ & $1.520(17)$ & $2.340(14)$ & $4.20(4)$ & $2.78(2)$ \\
\hline ICB1 & $104.2+1.3,-1.3$ & $101.1+2.8,-2.9$ & $0.0114(2)$ & $0.0060(1)$ & $0.679(5)$ & $2.796(48)$ & $4.120(67)$ & $16.21(12)$ & $5.19(8)$ \\
\hline ICB2 & $124.6+1.6,-1.6$ & $114.8+6.7,-7.0$ & $0.0163(2)$ & $0.0242(1)$ & $0.760(6)$ & $2.786(34)$ & $3.667(42)$ & $5.70(4)$ & $4.79(6)$ \\
\hline ICB3 & $126.9+2.2,-2.1$ & $125.4+2.9,-2.9$ & $0.0106(2)$ & $0.0030(1)$ & $0.774(8)$ & $3.360(59)$ & $4.343(67)$ & $35.70(48)$ & $5.78(9)$ \\
\hline ICB4 & $149.8+3.5,-3.4$ & $149.0+3.9,-3.8$ & $0.0179(2)$ & $0.0027(1)$ & $0.853(11)$ & $3.561(53)$ & $4.175(35)$ & $71.42(95)$ & $5.85(5)$ \\
\hline ICB5 & $166.7+2.4,-2.4$ & $165.3+3.2,-3.1$ & $0.0261(2)$ & $0.0064(1)$ & $0.899(7)$ & $3.254(32)$ & $3.619(28)$ & $40.56(34)$ & $5.19(4)$ \\
\hline ICB6 & $152.7+2.5,-2.5$ & $151.7+3.0,-3.0$ & 0 & 0 & $0.851(7)$ & $2.700(24)$ & $3.172(23)$ & 80.011 & 4.341 \\
\hline ICB7 & $175.9+1.9,-1.9$ & $174.8+2.5,-2.4$ & 0.0761 & 0.009 & 0.902 & $2.224(11)$ & $2.465(7)$ & $56.58(27)$ & $3.41(1)$ \\
\hline ICB8 & $149.0+1.3,-1.3$ & $147.9+1.9,-1.9$ & $0.0597(3)$ & $0.0088(1)$ & $0.837(4)$ & $2.492(11)$ & $2.978(8)$ & $51.43(38)$ & $4.01(1)$ \\
\hline FA7 & $426+32,-27$ & $414+39,-34$ & $0.0861(4)$ & $0.1299(11)$ & $1.161(11)$ & $2.288(21)$ & $1.971(6)$ & $4.60(5)$ & $4.23(1)$ \\
\hline FA12 & $247.1+5.5,-5.3$ & $235+12,-12$ & $0.0949(5)$ & $0.0644(3)$ & $0.963(6)$ & $1.320(6)$ & $1.370(6)$ & $5.91(3)$ & $1.74(1)$ \\
\hline FA12R & $243.7+7.1,-6.7$ & $231+14,-14$ & $0.0958(5)$ & $0.0748(4)$ & $0.971(9)$ & $1.428(12)$ & $1.470(3)$ & $5.55(5)$ & $1.94(1)$ \\
\hline FA57 & $140.4+1.9,-1.9$ & $117+14,-16$ & $0.0993(5)$ & $0.1093(7)$ & $0.760(5)$ & $1.061(7)$ & $1.395(4)$ & $2.93(2)$ & $1.59(1)$ \\
\hline TH1 & $28.6+0.2,-0.2$ & $26.0+1.6,-1.6$ & $0.0301(2)$ & $0.0120(1)$ & $0.238(2)$ & $1.021(7)$ & $4.296(14)$ & $7.79(5)$ & $4.57(2)$ \\
\hline TH2 & $125.8+0.9,-0.9$ & $113.7+7.3,-7.8$ & $0.0277(2)$ & $0.0308(2)$ & $0.748(4)$ & $1.757(8)$ & $2.350(7)$ & $4.81(2)$ & $2.93(1)$ \\
\hline TH3 & $209.3+8.6,-8.0$ & $201+13,-12$ & $0.1277(8)$ & $0.0953(5)$ & $0.961(14)$ & $1.989(19)$ & $2.069(27)$ & $8.10(7)$ & $2.93(4)$ \\
\hline TH4 & $64.8+0.5,-0.5$ & $46+10,-12$ & $0.1353(7)$ & $0.2527(21)$ & $0.474(3)$ & $1.399(8)$ & $2.950(7)$ & $2.27(2)$ & $3.34(1)$ \\
\hline ON5 & $67.9+1.3,-1.2$ & $64.8+2.8,-2.8$ & $0.1118(7)$ & $0.0309(2)$ & $0.488(7)$ & $1.176(9)$ & $2.408(30)$ & 12.94(9) & $2.71(3)$ \\
\hline ON12 & $78.0+.5,-0.5$ & $75.6+1.8,-1.8$ & $0.2090(11)$ & (2) & 0.5 & (6) & $2.276(5)$ & $18.29(8)$ & $2.59(1)$ \\
\hline ON23 & $157.6+1.2,-1.2$ & $156.0+2.1,-2.0$ & $0.5180(26)$ & $0.0457(2)$ & $0.808(3)$ & $1.138(3)$ & $1.409(3)$ & $39.22(10)$ & $1.64(1)$ \\
\hline ON35 & $158.1+1.3,-1.3$ & $155.4+2.7,-2.7$ & $0.3152(16)$ & $0.0431(2)$ & $0.804(3)$ & $1.085(3)$ & $1.349(3)$ & $24.05(6)$ & $1.54(1)$ \\
\hline FR2 & $75.2+0.5,-0.5$ & $61.9+7.5,-8.2$ & $0.0314(2)$ & $0.0566(3)$ & $0.535(3)$ & $1.980(11)$ & $3.703(11)$ & $3.34(2)$ & $4.34(10$ \\
\hline FR5 & $123.9+1.8,-1.8$ & $95+18,-21$ & $0.0661(4)$ & $0.1179(6)$ & $0.726(6)$ & $1.298(11)$ & $1.787(7)$ & $2.21(2)$ & $2.12(1)$ \\
\hline FRCT & $312.5+3.7,-3.6$ & $305.7+7.2,-7.3$ & $1.0320(52)$ & $0.9994(73)$ & $1.121(3)$ & $2.730(8)$ & $2.435(2)$ & $8.56(5)$ & $4.47(1)$ \\
\hline
\end{tabular}

